\title{
Data report: particle size analysis of sediments in the Ursa Basin, IODP Expedition 308 Sites U1324 and U1322, northern Gulf of Mexico'
}

\author{
Derek E. Sawyer, ${ }^{2}$ Ryan Jacoby, ${ }^{3}$ Peter Flemings, ${ }^{2}$ and John T. Germaine ${ }^{4}$
}

\section{Chapter contents}

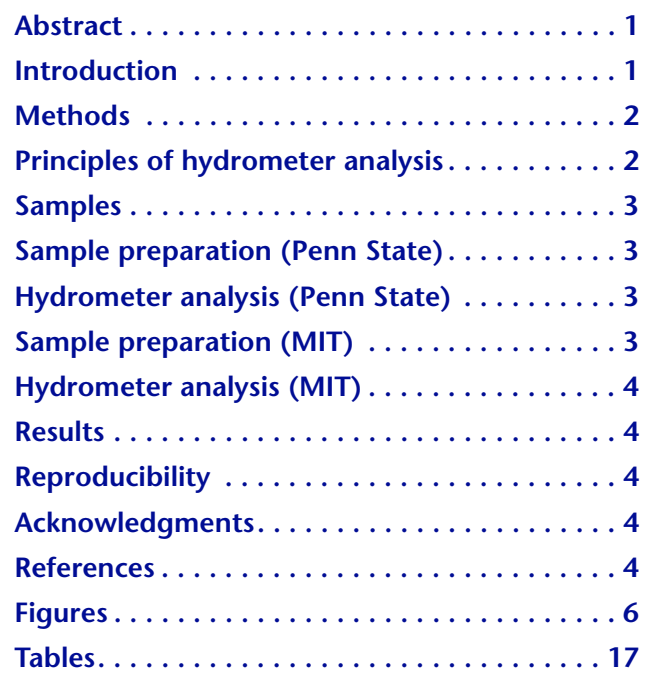

'Sawyer, D.E., Jacoby, R., Flemings, P., and Germaine, J.T., 2008. Data report: particle size analysis of sediments in the Ursa Basin, IODP Expedition 308 Sites U1324 and U1322, northern Gulf of Mexico. In Flemings, P.B., Behrmann, J.H., John, C.M., and the Expedition 308 Scientists, Proc. IODP, 308: College Station, TX (Integrated Ocean Drilling Program Management International, Inc.).

doi:10.2204/iodp.proc.308.205.2008

${ }^{2}$ Jackson School of Geosciences, The University of Texas at Austin, Austin TX 78712-0254, USA. Correspondence author: derek.sawyer@mail.utexas.edu ${ }^{3}$ Department of Geosciences, The Pennsylvania State University, University Park PA 16802, USA. ${ }^{4}$ Department of Civil and Environmental Engineering, The Massachusetts Institute of Technology, Cambridge MA 02139, USA.

\section{Abstract}

We conducted particle size analyses on 340 samples from Integrated Ocean Drilling Program Expedition 308 Sites U1324 (246 samples) and U1322 (94 samples) in the Ursa Basin (Gulf of Mexico) and found two characteristic lithologies: silty clay and clayey silt. Silty clays are composed of $\sim 60 \%( \pm 10 \%)$ clay-sized particles by weight, $\sim 40 \%$ silt-sized particles by weight, and $<1 \%$ sandsized particles by weight. Clayey silts are generally composed of $\sim 30 \%$ clay-sized particles by weight, $65 \%-70 \%$ silt-sized particles by weight, and $0 \%-5 \%$ sand-sized particles by weight. Site U1322 is dominated by silty clays with little particle size variation throughout the cored interval (0-235 meters below seafloor [mbsf]). At Site U1324, both lithologies occur where the lowermost section ( 360-608 mbsf) is dominated by clayey silt and the uppermost section ( $0-360 \mathrm{mbsf})$ is dominated by silty clay.

\section{Introduction}

Integrated Ocean Drilling Program (IODP) Expedition 308 was aimed at understanding how geology, pressure, and stress combine to control overpressure and fluid flow on the Gulf of Mexico continental slope (see the "Expedition 308 summary" chapter). We focused on two areas: a reference site, Brazos-Trinity Basin IV, and an overpressured area, the Ursa Basin. The Ursa Basin is located $\sim 200 \mathrm{~km}$ southeast of Louisiana (USA) in $\sim 1000 \mathrm{~m}$ of water directly downdip of rapid Pleistocene sedimentation from the Mississippi River system (Fig. F1). In the uppermost 1000 meters below seafloor (mbsf) in the Ursa Basin, a sand-rich permeable unit, the Blue Unit, was buried rapidly and asymmetrically by an eastward-thinning mud-rich overburden (Fig. F2) (Winker and Booth, 2000; Winker and Shipp, 2002; Sawyer et al., 2007b; see the "Expedition 308 summary" chapter).

At Site U1324 in the Ursa Basin, we cored a $608 \mathrm{~m}$ thick succession, including the eastern levee of the Southwest Pass Canyon, overlying distal turbidites, and hemipelagic drape (see the "Site U1324" chapter). At Site U1322, we cored a stacked succession of mass transport deposits, distal turbidites, and hemipelagic drape (see the "Site U1322" chapter). In general, these sediments were identified by shipboard sedimentologists as predominantly fine grained (silt and clay) with little sand (see the "Expedition 308 summary" chapter). However, shipboard analyses could not quan- 
tify the relative proportion of clay, silt, and sand, which also prevented proper lithologic classification.

Most lithologic classification schemes for clastic sediments rely on determining the relative percentage of clay-sized particles, silt-sized particles, and sandsized particles (Wentworth, 1922). These textural data are then used to name the rock/sediment type, for which numerous conventions exist (Shepard, 1954; Krumbein and Sloss, 1963; Folk, 1968; Blatt et al., 1980; Potter et al., 1980). "Mud" is a generic term referring to sediments composed predominantly of particles finer than $63 \mu \mathrm{m}$, which includes silt- and clay-sized particles (Aplin et al., 1999; Potter et al., 2005; Yang and Aplin, 2007). In the Ursa Basin, we encountered sediments that were almost exclusively composed of particles finer than $63 \mu \mathrm{m}$ (see the "Expedition 308 summary" chapter). To avoid naming all samples "mud" in this report, we adopted the Shepard (1954) classification (Fig. F3).

Our objective was to create a downcore profile of particle size at both sites, which is critical for permeability constraints in numerical fluid flow models, and which will help illuminate the stratigraphic history of the Ursa Basin. We analyzed 340 samples (Tables T1, T2), which were primarily from $10 \mathrm{~cm}^{3}$ plug samples taken shipboard and whole-core trimmings from constant-rate-of-strain (CRS) consolidation tests (see Long et al.). We employed standard wetsieve and hydrometer techniques to measure particle size distribution and the relative percentages of sand, silt, and clay in each sample. Here we describe our experimental background and procedure and present the overall results. Individual data files for each experiment can be found in "Supplementary material."

\section{Methods}

Samples were analyzed at the Pennsylvania State University (Penn State) and the Massachusetts Institute of Technology (MIT), using the standard hydrometer method (ASTM D422-63, 2003). We chose this method because we have considerable experience using this technique on fine-grained soils, the method is capable of processing large samples $(>20$ g) with no minimum particle size restrictions, and it is internationally recognized as a standard in the American Standard for Testing and Materials (ASTM D422-63; ASTM International, 2003) and in the British Standard Institution (BS 1377; British Standards Institution, 1990).

Specific gravity was determined on a representative subset of samples at MIT according to ASTM Standard D854-06 (ASTM International, 2006), which is a water pycnometer method. In this method, the mass of a pycnometer (of known volume) that is filled with deaired water and a small amount of soil are compared with the same pycnometer filled only with deaired water.

The hydrometer method used here is in general accordance with ASTM D422-63 (ASTM International, 2003) guidelines, but we describe the slightly different approaches taken at Penn State and MIT below. In addition to the hydrometer method, other authors have used laser particle and pipette analyses for measuring particle size distribution in mud-rich samples (Folk, 1968; McCave and Syvitski, 1991; Lewis and McConchie, 1994; Loizeau et al., 1994; Cramp et al., 1997; Konert and Vandenberghe, 1997).

\section{Principles of hydrometer analysis}

The physical principles of sedimentation underlying the hydrometer analysis are presented in a number of texts including Das (2002); we briefly review them here. The hydrometer analysis applies Stokes's law, which governs the terminal velocity at which spherical particles settle through a column of fluid (Craig, 1992). Stokes's law assumes particles that (1) are rigid, spherical, and smooth; (2) have similar density; (3) are separated from each other; (4) do not interact during sedimentation; and (5) are large enough so that settlement is not governed by Brownian motion. The law is also strictly applicable to slow fluid movements that display laminar flow patterns (i.e., Reynolds number $=<1$ ) (Wen et al., 2002).

Hydrometer analysis begins after thoroughly mixing the sediment and water, after which particles settle out of the water column according to Stokes's law. The density of a sediment-water suspension depends on the concentration and specific gravity of the sediments present in the mixture. If the suspension is allowed to stand, particles will settle out of the suspension and the density of the sediment-water suspension will decrease. A hydrometer measures the density of the suspension at a known depth below the surface.

The two basic calculations made during a hydrometer analysis are the particle diameter at a specific time and depth and the percentage of the original sample mass still left in suspension. We calculate the particle diameter according to the following equation:

$$
D=\sqrt{\frac{30 \eta}{\left(G_{\mathrm{s}}-1\right)}} \sqrt{\frac{L}{t}}
$$

where

$$
D=\text { equivalent sedimentation diameter of particle }
$$


$\eta=$ viscosity of water (grams seconds per square centimeter),

$G_{s}=$ specific gravity of sediment,

$L=$ effective depth measured from water surface to center of gravity of hydrometer bulb (centimeters), and

$t=$ time measured from start of sedimentation (seconds).

The percentage of particles remaining in suspension finer than particle diameter, $D$, is

$$
\text { \%Finer }=\frac{G_{\mathrm{s}}}{G_{\mathrm{s}}-1} \times \frac{V}{M} \times \frac{\left(R_{\mathrm{h}}-B\right)}{10},
$$

where

$$
\begin{aligned}
G_{\mathrm{s}}= & \text { specific gravity of sediment, } \\
V= & \text { total water-sediment volume }(1000 \mathrm{~mL}), \\
M= & \text { dry sample mass (grams), } \\
R_{\mathrm{h}}= & \text { corrected hydrometer reading of slurry mix- } \\
& \text { ture (grams per liter), and } \\
B= & \text { hydrometer reading of reference mixture of } \\
& \text { dispersing agent and distilled water (grams per } \\
& \text { liter). }
\end{aligned}
$$

\section{Samples}

Two types of samples were used in this study: shipboard samples taken approximately every 1-2 m (9-40 g) and trimmings from whole-core geotechnical samples (20-50 g) that were used for shore-based consolidation tests (see Long et al.).

\section{Sample preparation (Penn State)}

Samples were prepared differently at each university, with prehydrometer analysis sand content obtained only at Penn State using a wet-sieve analysis (sievehydrometer method). Samples were first manually disaggregated and placed in a drying oven at $55^{\circ} \mathrm{C}$ for at least $16 \mathrm{~h}$ before recording dry masses. Dried samples were mixed with $5 \mathrm{~g}$ of dispersing agent (sodium hexametaphosphate) and $\sim 200 \mathrm{~mL}$ of deionized water and tempered for another $24-48 \mathrm{~h}$. The mixture was further disaggregated for 2 min using the ASTM-recommended Hamilton-Beach malt mixer (ASTM D422-63; ASTM International 2003).

To measure sand content of samples, the slurry was washed with deionized water through a $62.5 \mu \mathrm{m}$ sieve and the retained portion was dried and weighed. This process provided the percentage of sand by weight for each sample processed at Penn State.
The remaining fine-grained slurry was poured into a $1000 \mathrm{~mL}$ plastic cylinder and filled with deionized water to create a solution of $1000 \mathrm{~mL}$. We generally prepared 8-16 cylinders before initiating the hydrometer analysis. One cylinder containing only distilled water and $5 \mathrm{~g}$ of dispersing agent was also prepared so that reference hydrometer readings could be made and then used to make water density corrections (as described below). A total of 311 samples were analyzed at Penn State (Tables T1, T2). In addition, seven of the samples taken from the remnants of whole-core samples were prepared for reproducibility experiments, the results of which we discuss below.

\section{Hydrometer analysis (Penn State)}

Prior to the start of each experiment, each cylinder was mixed for 2 min using a plunging rod. Once the rod was removed, the stopwatch was started and the hydrometer was inserted and steadied. Readings were made at 15 and $30 \mathrm{~s}$ without removing the hydrometer. After the $30 \mathrm{~s}$ reading (and each subsequent reading), the hydrometer was removed, rinsed in deionized water, and wiped dry before obtaining readings at $1,2,4,8,16$, and up to at least $1024 \mathrm{~min}$. Hydrometer readings were recorded to the nearest $0.1 \mathrm{~g} / \mathrm{L}$.

An example data sheet and plot are given in Figures F4 and F5, respectively. We made continuous hydrometer readings on the reference mixture, $B$, which contained distilled water and dispersing agent. Reading $B$ was then subtracted from the suspension reading, $R_{\mathrm{h}}$, in Equation 2 . We continually monitored temperature in the laboratory and updated water viscosity, $\eta$, accordingly. The effective depth, $L$, in Equation 1, is hydrometer-specific and was calculated according to a prescribed calibration procedure (Lewis and McConchie, 1994).

Specific gravity of the sample, $G_{\mathrm{s}}$, in Equations 1 and 2 , was determined on a representative subset of 19 samples obtained at MIT in general accordance with ASTM Standard D854-06 (ASTM International, 2006). These measurements are presented in Table T4. Measurements ranged between 2.65 and 2.77 . For samples where no specific gravity measurements were made, we used an average value of 2.70 for evaluating Equations 1 and 2.

\section{Sample preparation (MIT)}

Air-dried samples were mixed with $5 \mathrm{~g}$ of sodium hexametaphosphate and distilled water. The solu- 
tion was allowed to temper for $16 \mathrm{~h}$ before it was mixed in the ASTM-recommended Hamilton Beach malt mixer for $1 \mathrm{~min}$ and transferred to a $1000 \mathrm{~mL}$ cylinder. Distilled water was added to the cylinder to create a $1000 \mathrm{~mL}$ suspension, and the tube was placed in a constant-temperature water bath. Only one cylinder was prepared at a time before starting the hydrometer analysis. A total of 29 samples were analyzed using this method (Tables T1, T2).

\section{Hydrometer analysis (MIT)}

The prepared suspension was mixed thoroughly with a plunging rod for $1 \mathrm{~min}$. The removal of the plunging rod marked the beginning of the sedimentation process. Two sets of hydrometer readings were obtained for the first $2 \mathrm{~min}(4,14,30,60,90$, and 120 s) of sedimentation with the hydrometer remaining in the suspension. Readings were recorded to 0.2 of a graduation by estimating five increments between graduations. The slurry was then remixed, and additional readings were made at $2,4,8,16$, and $32 \mathrm{~min}$, for up to 2 days. At the end of the experiment, the slurry was poured into an evaporating dish and dried in an oven to obtain the final mass of sediment and dispersing agent. The basic measurements and constants in this method are the same as described for Penn State in Figures F4 and F5, respectively.

\section{Results}

We conducted particle size distribution curves for 340 samples at Penn State and MIT. Sand, silt, and clay percentages are given in Table T1 for Site U1322 and in Table T2 for Site U1324. Data sheets and curves similar to Figures F4 and F5 for each sample are available in Excel format in "Supplementary material."

We plot the downcore profile of percent sand, silt, and clay against gamma ray and resistivity logs for Sites U1322 and U1324 in Figures F6 and F7, respectively.

We plot sand, silt, and clay percentages for all samples from both sites on a single classification chart in Figure F8. In Figure F9, we plot results for Sites U1322 and U1324 separately. Nearly all samples from Site U1322 plot as silty clay, whereas samples from Site U1324 are scattered in a wide range in both silty clay and clayey silt fields. The four sand samples are from Site U1324 ( 305 mbsf) (Fig. F7).

From our particle size analyses of the Ursa Basin samples, we define two characteristic lithologies: silty clay and clayey silt. Silty clays are generally composed of $\sim 60 \%$ ( $\pm 10 \%$ ) clay-sized particles by weight, $\sim 40 \%$ silt-sized particles by weight, and $<1 \%$ sand- sized particles by weight. Ursa Basin clayey silts are generally composed of $\sim 65 \%-70 \%$ silt-sized particles by weight, $30 \%$ clay-sized particles by weight, and 0\%-5\% sand-sized particles by weight.

\section{Reproducibility}

We used samples from whole-core trimmings to run repeat experiments from whole-core trimmings at Penn State to gauge the reproducibility of our experiments. We conducted two types of tests: multiple hydrometer runs on a single sample and hydrometer runs on a single sample in which we varied the initial dry mass. We show an example of each type of test in Figures F10 and F11.

Samples were prepared by "cone and quartering" to ensure homogeneity. In this process, sediment is mixed and piled into a cone that is then divided into quarters, and opposite quarters are combined.

The first-order results of our experiments show that particle size distribution curves from both types of tests generally match each other (Figs. F10, F11). A statistical treatment of the reproducibility experiments was conducted by the Statistical Consulting Center at Penn State. They applied a cubic-spline regression method and concluded that our experiments are fairly consistent and reproducible.

We did not test the reproducibility of the experiments performed at MIT. However, the equipment, materials, and procedures used at MIT were very similar to those used at Penn State. Furthermore, we distinguish the MIT experiments as red squares in Figures F6 and F7 to show that the MIT experiments lie within the expected range of results.

\section{Acknowledgments}

All samples used in this study were collected during IODP Expedition 308. Funding for this research was provided by the U.S. Science Support Program, administered by the Consortium for Ocean Leadership (formerly Joint Oceanographic Institutions). This research was also sponsored by the Petroleum Research Fund (PRF 44476-AC8). We thank the crew and science party from Expedition 308. H. Nelson and L. Arnold provided help with formatting data sheets, figures, and digital files. We thank Y. Feng and T. Yang for statistical analysis of reproducibility tests. We thank I.W. Aiello for a helpful review.

\section{References}

Aplin, A.C., Fleet, A.J., and Macquaker, J.H.S., 1999. Muds and mudstones: physical and fluid flow properties. In 
Aplin, A.C., Fleet, A.J., and Macquaker, J.H.S. (Eds.), Muds and Mudstones: Physical and Fluid Flow Properties. Geol. Soc. Spec. Pub., 158:1-8.

ASTM International, 2003. Standard test method for particle-size analysis of soils (Standard D422-63[2002]). In Annual Book of ASTM Standards (Vol. 04.08): Soil and Rock (I): West Conshohocken, PA (Am. Soc. Testing and Mater.), 10-17.

ASTM International, 2006. Standard test methods for specific gravity of soil solids by water pycnometer (D85406). In Annual Book of ASTM Standards (Vol 04.08): Soil and Rock (I): West Conshohocken, PA (Am. Soc. Testing and Mater.).

Blatt, H., Middleton, G., and Murray, R., 1980. Origin of Sedimentary Rocks (2nd ed.): Englewood Cliffs, NJ (Prentice-Hall).

British Standards Institution, 1990. Methods of Test for Soils for Civil Engineering Purposes (Pt. 2): Classification Tests (Rep. BS 1377): London (British Standards Inst.).

Craig, R.F., 1992. Soil Mechanics (5th ed.): London (Chapman and Hall).

Cramp, A., Lee, S.V., Herniman, J., Hiscott, R.N., Manley, P.L., Piper, D.J.W., Deptuck, M., Johnston, S.K., and Black, K.S., 1997. Data report: interlaboratory comparison of sediment grain-sizing techniques: data from Amazon Fan upper levee complex sediments. In Flood, R.D., Piper, D.J.W., Klaus, A., and Peterson, L.C. (Eds.), Proc. ODP, Sci. Results, 155: College Station, TX (Ocean Drilling Program), 217-228. doi:10.2973/

odp.proc.sr.155.242.1997

Das, B.M., 2002. Principles of Geotechnical Engineering (5th ed.): St. Paul, MN (Brooks Cole).

Folk, R.L., 1968. Petrology of Sedimentary Rocks: Austin, TX (Univ. Texas).

Konert, M., and Vandenberghe, J., 1997. Comparison of laser grain size analysis with pipette and sieve analysis: a solution for the underestimation of the clay fraction. Sedimentology, 44(3):523-535. doi:10.1046/ j.1365-3091.1997.d01-38.x

Krumbein, W.C., and Sloss, L.L., 1963. Stratigraphy and Sedimentation (2nd ed.): San Francisco, CA (W. H. Freeman and Co.).

Lewis, D.W., and McConchie, D.M., 1994. Analytical Sedimentology: New York (Chapman and Hall).

Loizeau, J.-L., Arbouille, D., Santiago, S., and Vernet, J.-P., 1994. Evaluation of a wide range laser diffraction grain size analyser for use with sediments. Sedimentology, 41(2):353-361. doi:10.1111/ j.1365-3091.1994.tb01410.x
McCave, I.N., and Syvitski, J.P.M., 1991. Principles and methods of geological particle size analysis. In Syvitski, J.P.M. (Ed.), Principles, Methods, and Application of Particle Size Analysis: New York (Cambridge Univ. Press), 3-21.

Potter, P.E., Maynard, J.B., and Depetris, P.J., 2005. Mud and Mudstones: Introduction and Overview: Berlin (SpringerVerlag).

Potter, P.E., Maynard, J.B., and Pryor, W.A., 1980. Sedimentology of Shale: Berlin (Springer-Verlag).

Sawyer, D.E., Flemings, P.B., and Dugan, B., 2007a. Lateral variations in core, $\log$, and seismic attributes of a mass transport complex in the Ursa Region, IODP Expedition 308, Northern Gulf of Mexico [paper presented at the Offshore Technology Conference, 5-8 May 2007, Houston, TX].

Sawyer, D.E., Flemings, P.B., Shipp, R.C., and Winker, C.D., 2007b. Seismic geomorphology, lithology, and evolution of the late Pleistocene Mars-Ursa turbidite region, Mississippi Canyon area, northern Gulf of Mexico. AAPG Bull., Vol. 91(2):215-234. doi:10.1306/ 08290605190

Shepard, F.P., 1954. Nomenclature based on sand-silt-clay ratios. J. Sediment. Petrol., 24:151-158.

Wen, B., Aydin, A., and Duzgoren-Aydin, S., 2002. A comparative study of particle size analyses by sieve-hydrometer and laser diffraction methods. Geotech. Test. J., 25(4):434-442.

Wentworth, C.K., 1922. A scale of grade and class terms of clastic sediments. J. Geol., 30:377-392.

Winker, C.D., and Booth, J.R., 2000. Sedimentary dynamics of the salt-dominated continental slope, Gulf of Mexico: integration of observations from the seafloor, near-surface, and deep subsurface. Deep-Water Reservoirs of the World: Proc. GCSSEPM 20th Annu. Res. Conf., 10591086.

Winker, C.D., and Shipp, R.C., 2002. Sequence stratigraphic framework for prediction of shallow water flow in the greater Mars-Ursa area, Mississippi Canyon area, Gulf of Mexico continental slope [22nd Annual GCSSEPM Foundation Bob F. Perkins Research Conference, Houston, TX, 8-11 December, 2002]. (Abstract) http://www.gcssepm.org/pubs/2002_ab_56.htm

Yang, Y., and Aplin, A.C., 2007. Permeability and petrophysical properties of 30 natural mudstones. J. Geophys. Res., 112(B3):B03206. doi:10.1029/2005JB004243

Initial receipt: 20 December 2007

Acceptance: 28 April 2008

Publication: 13 November 2008

MS 308-205 
Figure F1. Bathymetry map of the Ursa Basin with locations of Site U1324 and Site U1322 (red dots) (modified from Sawyer et al., 2007b). The Ursa Basin is downdip of the Mississippi River. Seismic line A-A' is shown in Figure F2. CI = contour interval.

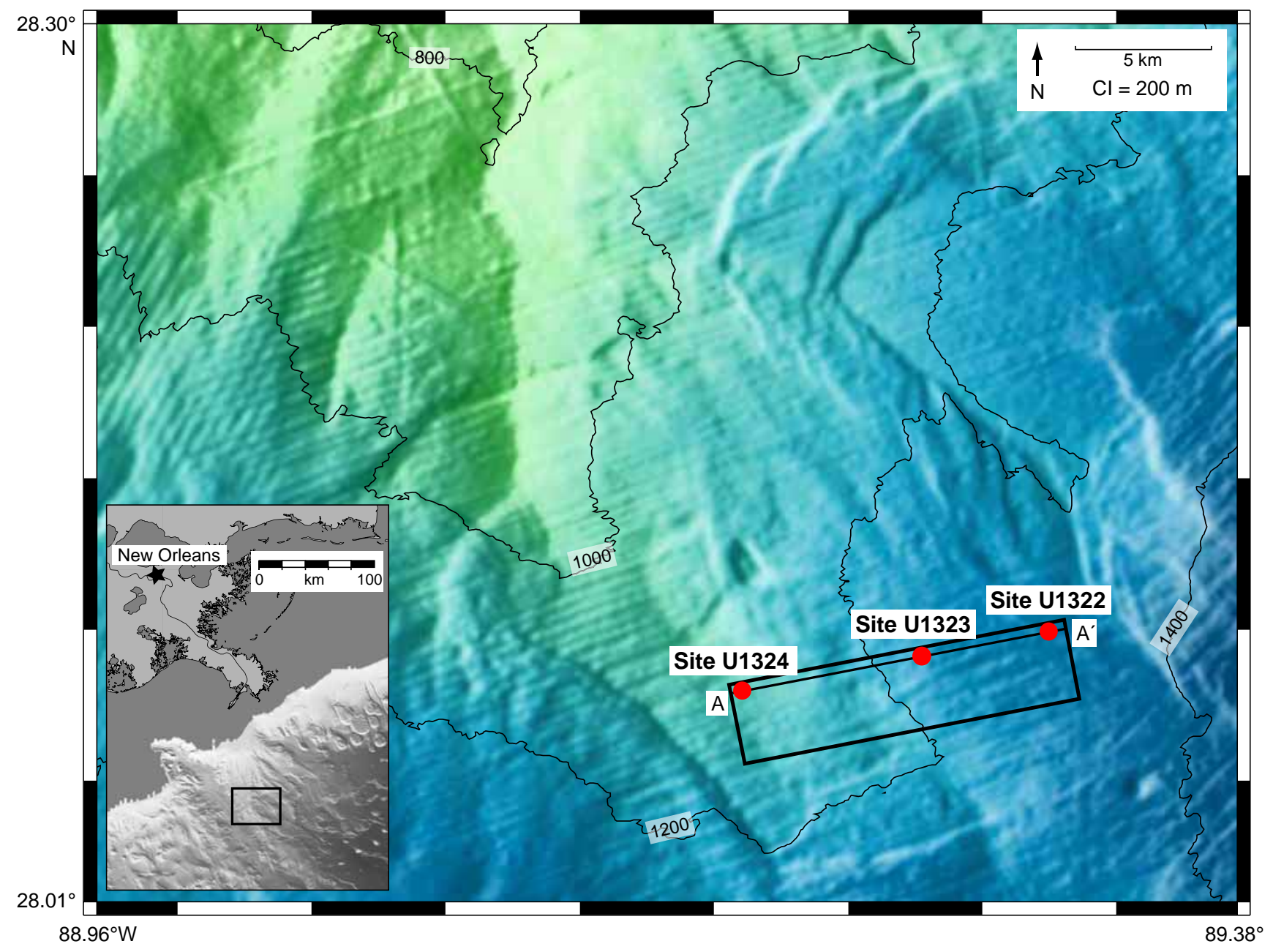


Figure F2. Seismic cross section $\mathrm{A}-\mathrm{A}^{\prime}$ through Expedition 308 sites and stratigraphic interpretation of seismic cross section (modified from Sawyer et al., 2007a). Seismic reflectors are defined in the "Expedition 308 summary" chapter. MTC = mass transport complex.
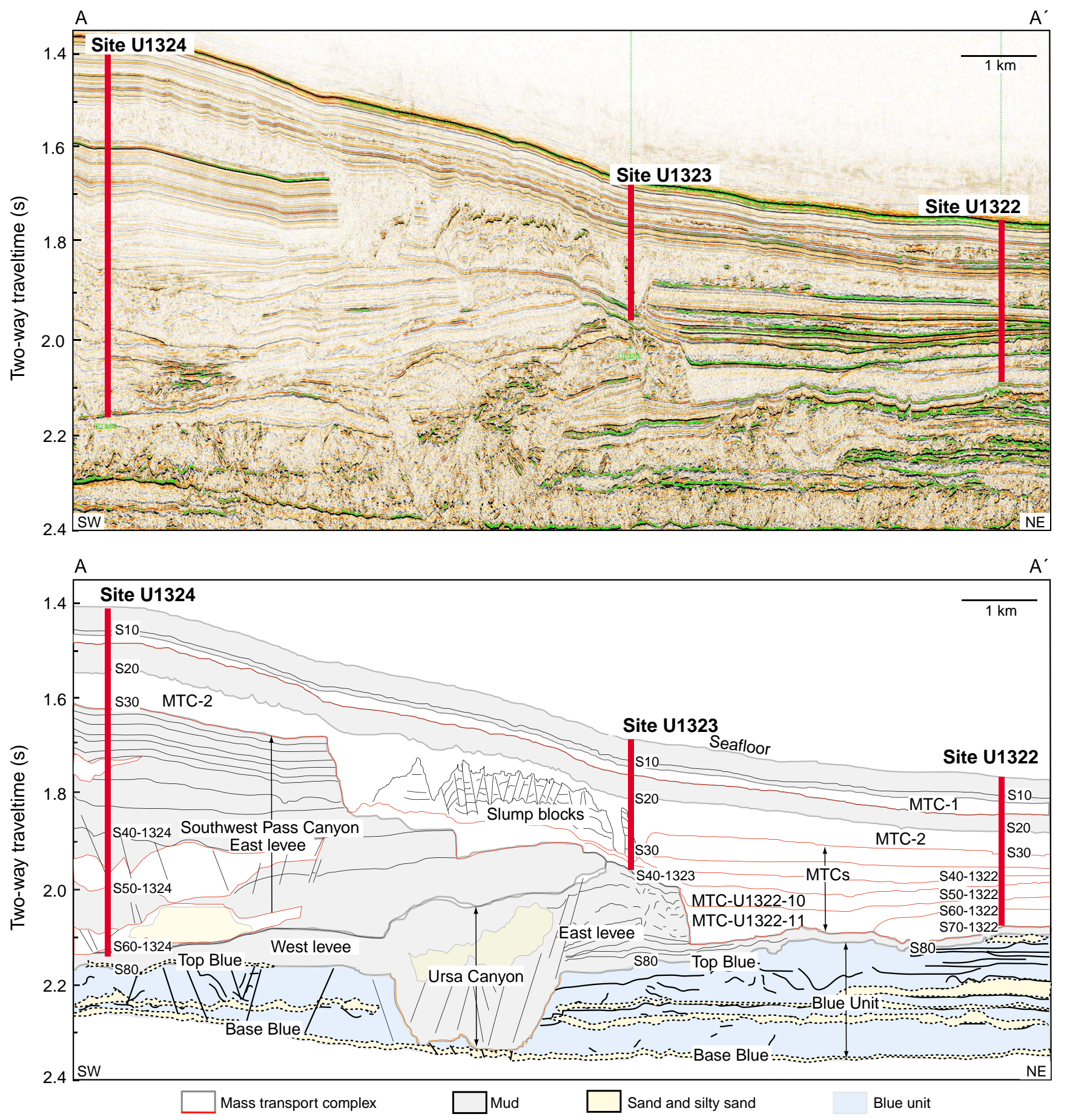
Figure F3. Shepard's (1954) classification ternary diagram based on relative percentages of sand, silt, and clay used to define lithology of Ursa Basin samples.

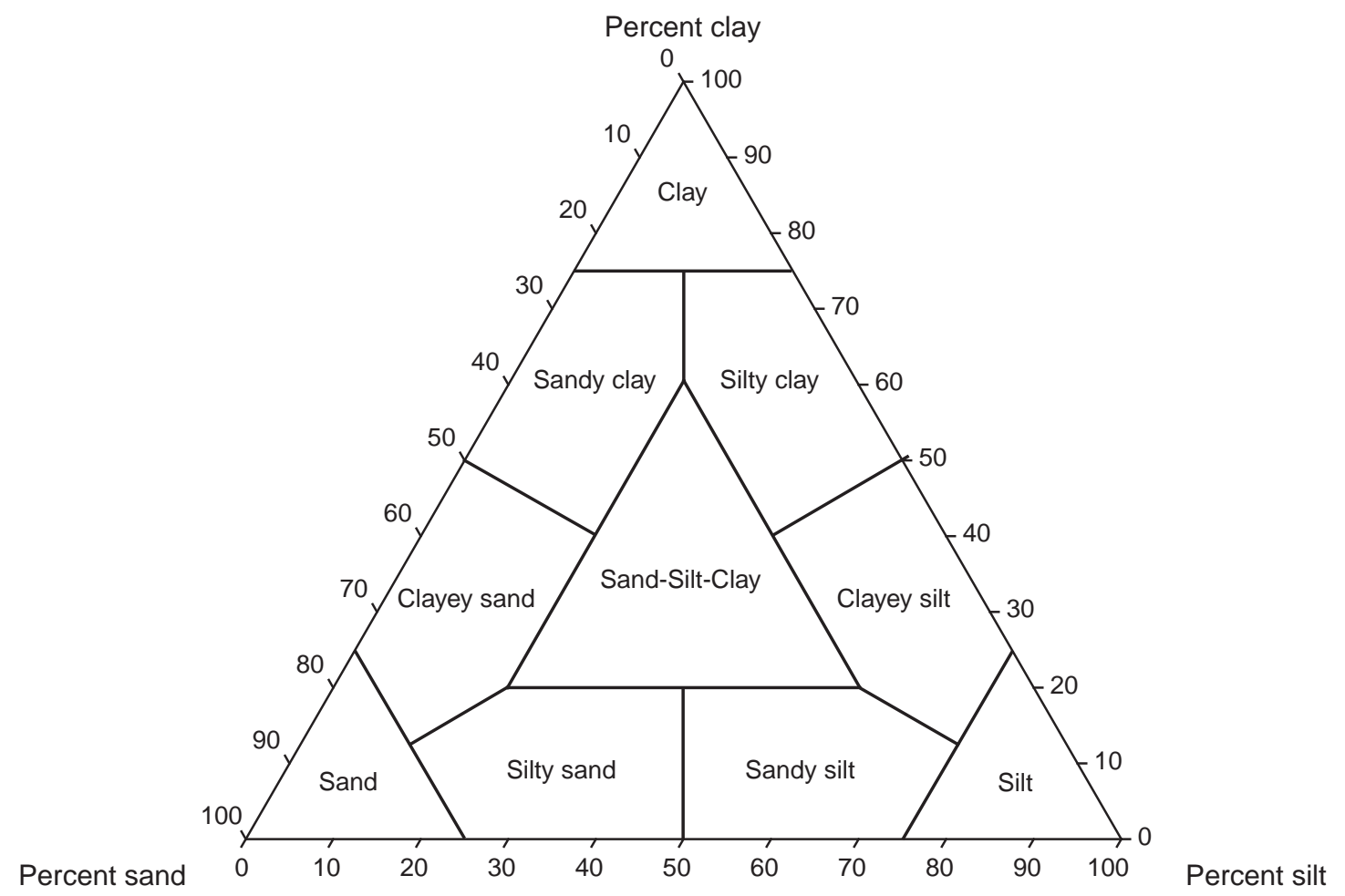


Figure F4. Sample data sheet for hydrometer analysis. $H_{\mathrm{r}}=$ hydrometer reading, effective depth $=$ depth $(L$ in Equation 1) of hydrometer's center, corrected for viscosity. Data sheets for all experiments are available in "Supplementary material."

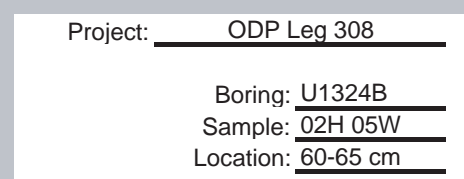

Location: $60-65 \mathrm{~cm}$

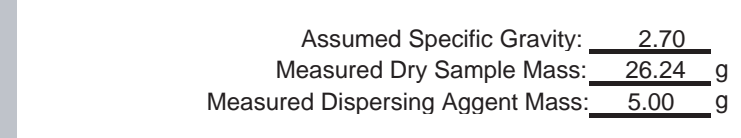

\begin{tabular}{|c|c|c|c|c|c|c|c|}
\hline \multicolumn{4}{|c|}{ Measurements } & \multicolumn{2}{|c|}{ Constants } & \multicolumn{2}{|c|}{ Results } \\
\hline $\begin{array}{c}\text { Elapsed Time } \\
\text { (min.) }\end{array}$ & $\begin{array}{c}\text { Susp'n Reading } \\
(\mathrm{g} / \mathrm{L})\end{array}$ & \begin{tabular}{|c|} 
Water + Disp'nt \\
Reading \\
$(\mathrm{g} / \mathrm{L})$ \\
\end{tabular} & $\begin{array}{c}\text { Temp. } \\
\left({ }^{\circ} \mathrm{C}\right)\end{array}$ & $\begin{array}{l}\text { Viscosity } \\
\left(\mathrm{g}-\mathrm{s} / \mathrm{cm}^{2}\right)\end{array}$ & $\begin{array}{l}\text { Effective Depth } \\
(\mathrm{cm})\end{array}$ & $\begin{array}{c}\% \text { Finer } \\
(\%)\end{array}$ & $\begin{array}{l}\text { Diameter } \\
(\mathrm{mm})\end{array}$ \\
\hline 0.25 & 1018.5 & 1002.6 & 23.9 & $9.36315 \mathrm{E}-06$ & 10.05789291 & 96.24 & 0.081532 \\
\hline 0.5 & 1018.4 & 1002.6 & 23.9 & $9.36315 \mathrm{E}-06$ & 10.08457167 & 95.63 & 0.057729 \\
\hline 1 & 1018.7 & 1002.6 & 23.9 & $9.36315 \mathrm{E}-06$ & 10.00453539 & 97.45 & 0.040658 \\
\hline 2 & 1018.7 & 1002.6 & 23.9 & $9.36315 \mathrm{E}-06$ & 10.00453539 & 97.45 & 0.028750 \\
\hline 4 & 1018.3 & 1002.7 & 23.9 & $9.36315 \mathrm{E}-06$ & 10.11125043 & 94.42 & 0.020437 \\
\hline 8 & 1017.0 & 1002.6 & 23.9 & $9.36315 \mathrm{E}-06$ & 10.45807433 & 87.16 & 0.014697 \\
\hline 16 & 1015.5 & 1002.5 & 23.9 & $9.36315 \mathrm{E}-06$ & 10.85825574 & 78.69 & 0.010589 \\
\hline 32 & 1014.4 & 1002.4 & 23.9 & $9.36315 \mathrm{E}-06$ & 11.15172211 & 72.63 & 0.007588 \\
\hline 64 & 1013.8 & 1002.5 & 23.9 & $9.36315 \mathrm{E}-06$ & 11.31179468 & 68.40 & 0.005404 \\
\hline 128 & 1012.8 & 1002.8 & 23.9 & $9.36315 \mathrm{E}-06$ & 11.57858229 & 60.53 & 0.003866 \\
\hline 256 & 1012.4 & 1002.9 & 24.0 & $9.34094 \mathrm{E}-06$ & 11.68529733 & 57.50 & 0.002743 \\
\hline 622 & 1011.6 & 1002.9 & 24.1 & 9.31882E-06 & 11.89872742 & 52.66 & 0.001774 \\
\hline 1253 & 1010.9 & 1002.8 & 24.0 & 9.34094E-06 & 12.08547875 & 49.03 & 0.001261 \\
\hline 2766 & 1009.9 & 1002.9 & 24.0 & 9.34094E-06 & 12.35226636 & 42.37 & 0.000858 \\
\hline
\end{tabular}

Hydrometer Analysis

\begin{tabular}{lr} 
Tydrometer & Test Number: $\frac{130}{\text { Tested by: } \frac{\text { RJJ }}{11 / 13 / 2006}}$ \\
\hline Type: $151 \mathrm{H}$ Fisher Brand & Test Date:
\end{tabular}

$\begin{aligned} \text { Number: } & \frac{}{98} \\ \text { Volume } & =\frac{72}{\mathrm{~cm}^{3}} \\ \mathrm{Hr} @ 1035 & =\frac{5.912}{15.212} \mathrm{~cm} \\ \mathrm{Hr} @ 1000 & =\frac{15}{0.8} \mathrm{~g} / \mathrm{L}\end{aligned}$

-Dispersing agent: Sodium

Hexametaphosphate

- Dispersing agent not included

in sample dry mass (wet sieved at 62.5 $\mu \mathrm{m}$ )

Mass retained on sieve (grams):

Sand-\% of dry mass:

$\%$ passing $0.0625 \mathrm{~mm}$ :
0.104

0.40

99.60
Interpolated value at silt/sand boundary $(2 \mu \mathrm{m})$

0.0625
$\%$ Finer

53.79
Diameter (mm) 0.002

Remarks/Comments: 
Figure F5. Sample particle size distribution plot on a semilog scale. Black circles = hydrometer readings, open triangle $=$ sand fraction from wet-sieving through $62.5 \mu \mathrm{m}$ sieve. Sand/silt boundary is defined at $62.5 \mu \mathrm{m}$, and silt/clay boundary is defined at $2 \mu \mathrm{m}$. Particle size distribution plots sheets for all experiments are available in "Supplementary material."

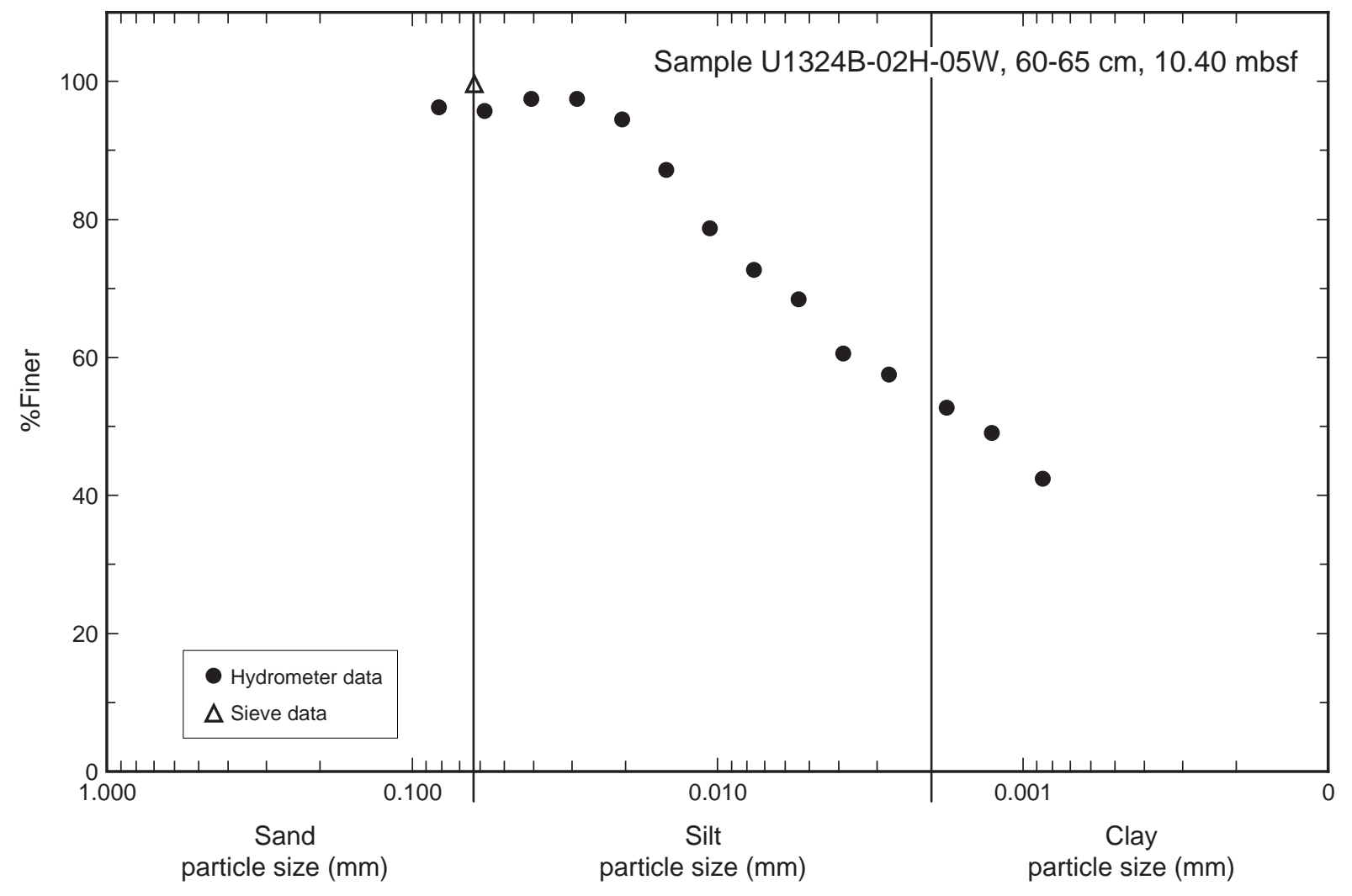


Figure F6. Downcore profile of particle distribution, Site U1322. Red squares = MIT measurements. Gamma ray and resistivity (P16B) logs are from wireline data. Lithologic units were defined by shipboard sedimentologists (see the "Site U1322" chapter).

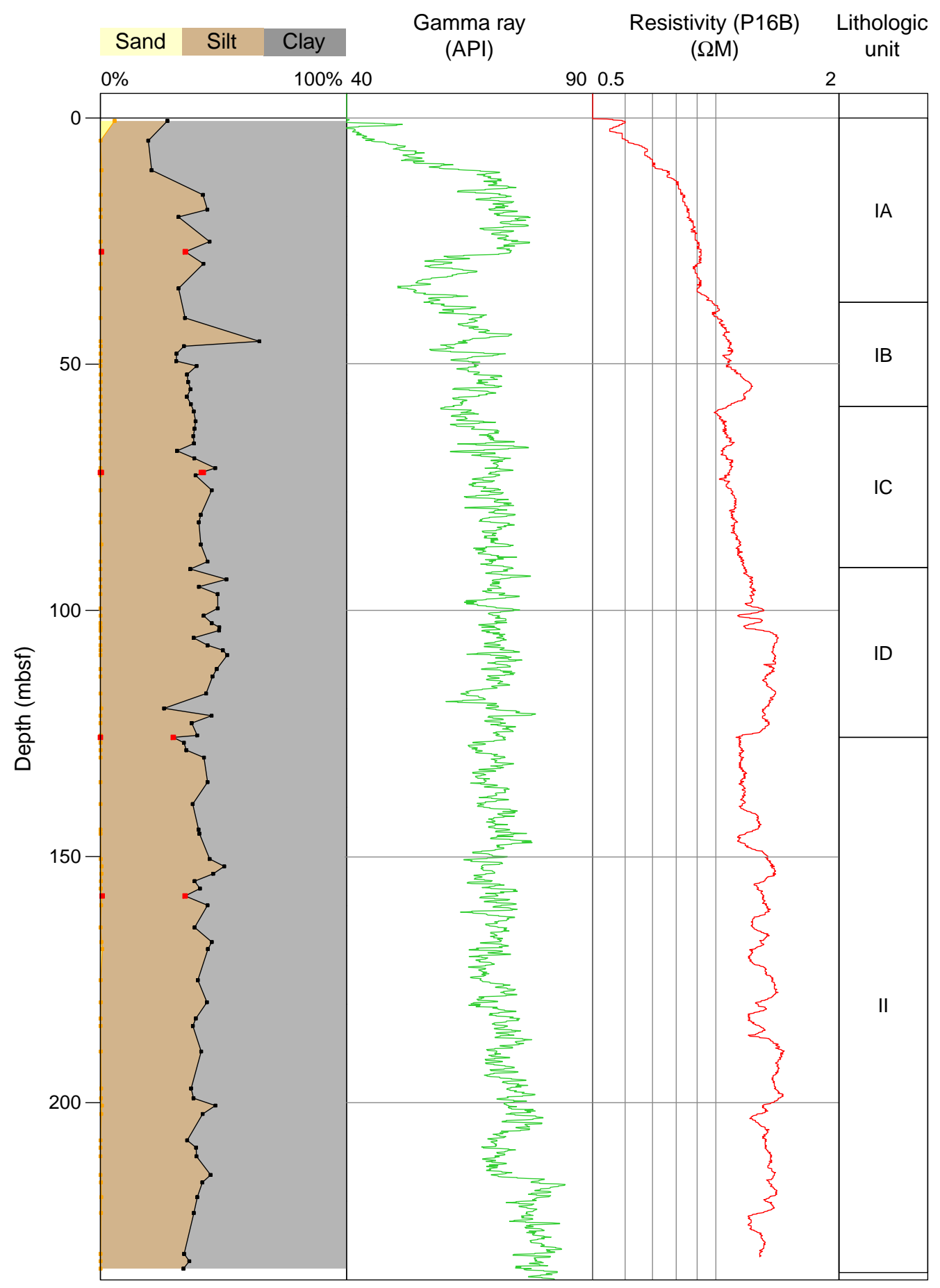


Figure F7. Downcore profile of particle distribution, Site U1324. Red squares = MIT measurements. Gamma ray and resistivity (P16B) logs are from wireline data. Lithologic units were defined by shipboard sedimentologists (see the "Site U1324" chapter).

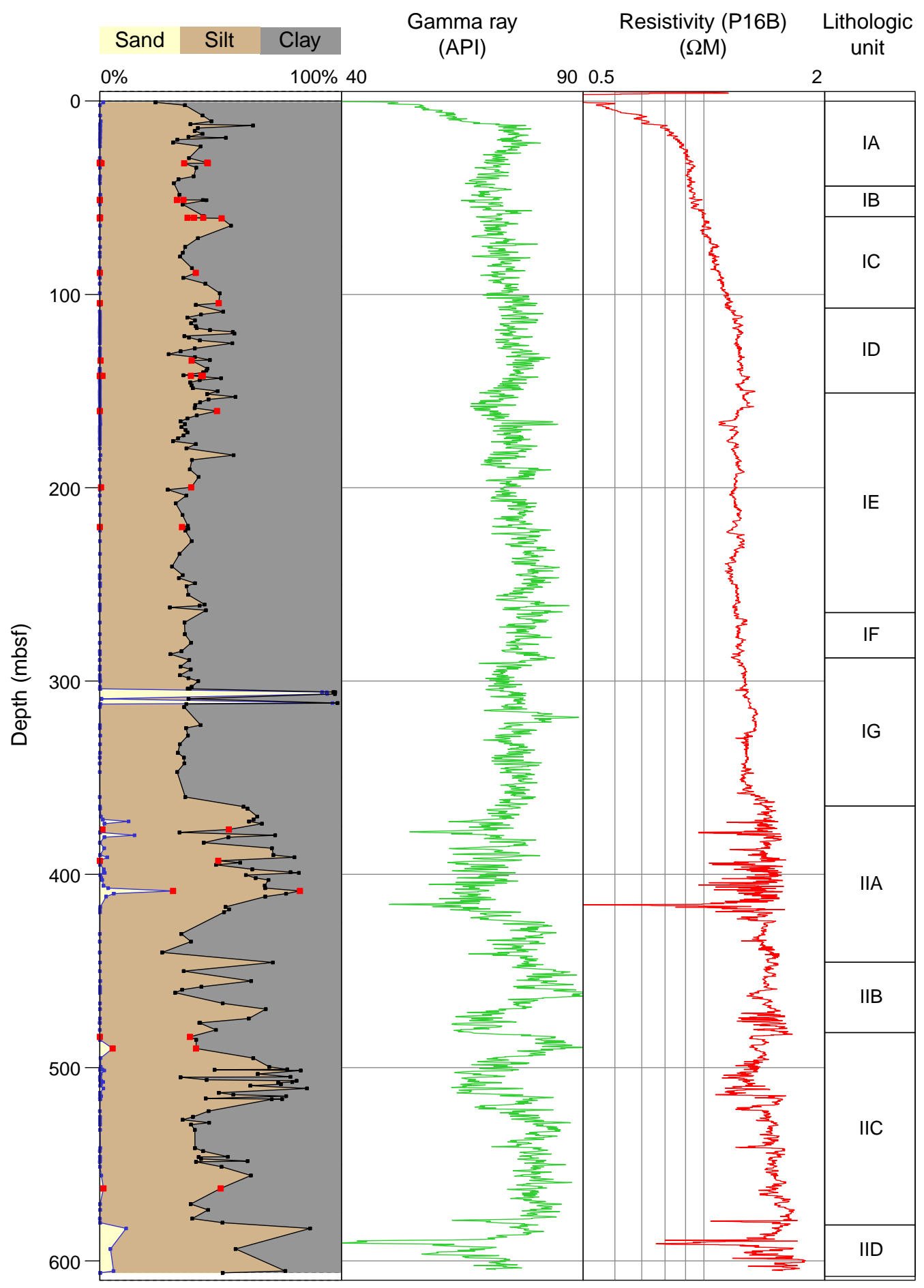


Figure F8. Ternary diagrams for all 340 samples from Site U1324 (gray circles) and Site U1322 (black circles).

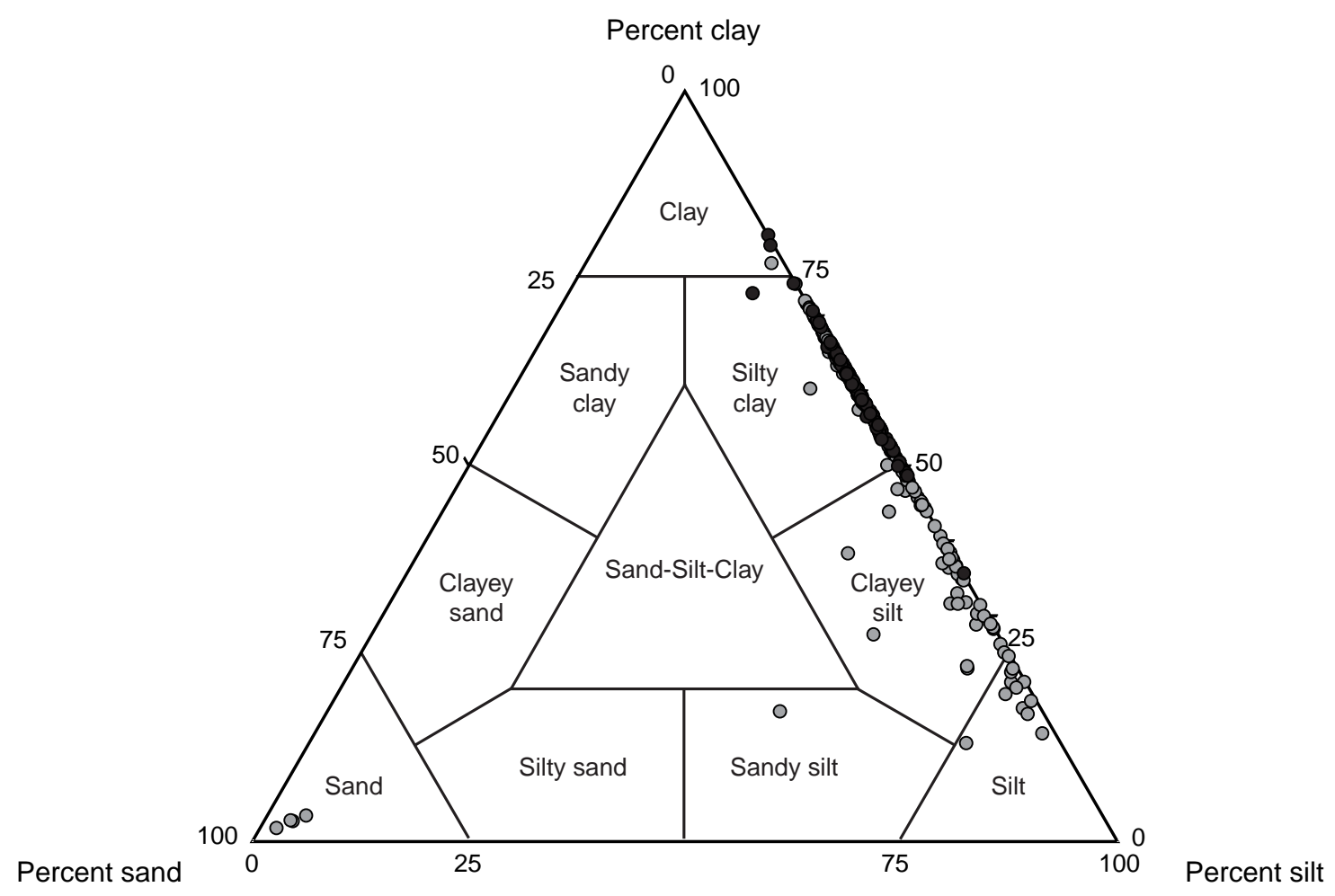


Figure F9. Ternary diagrams for (A) Site U1322 samples and (B) Site U1324 samples.

A

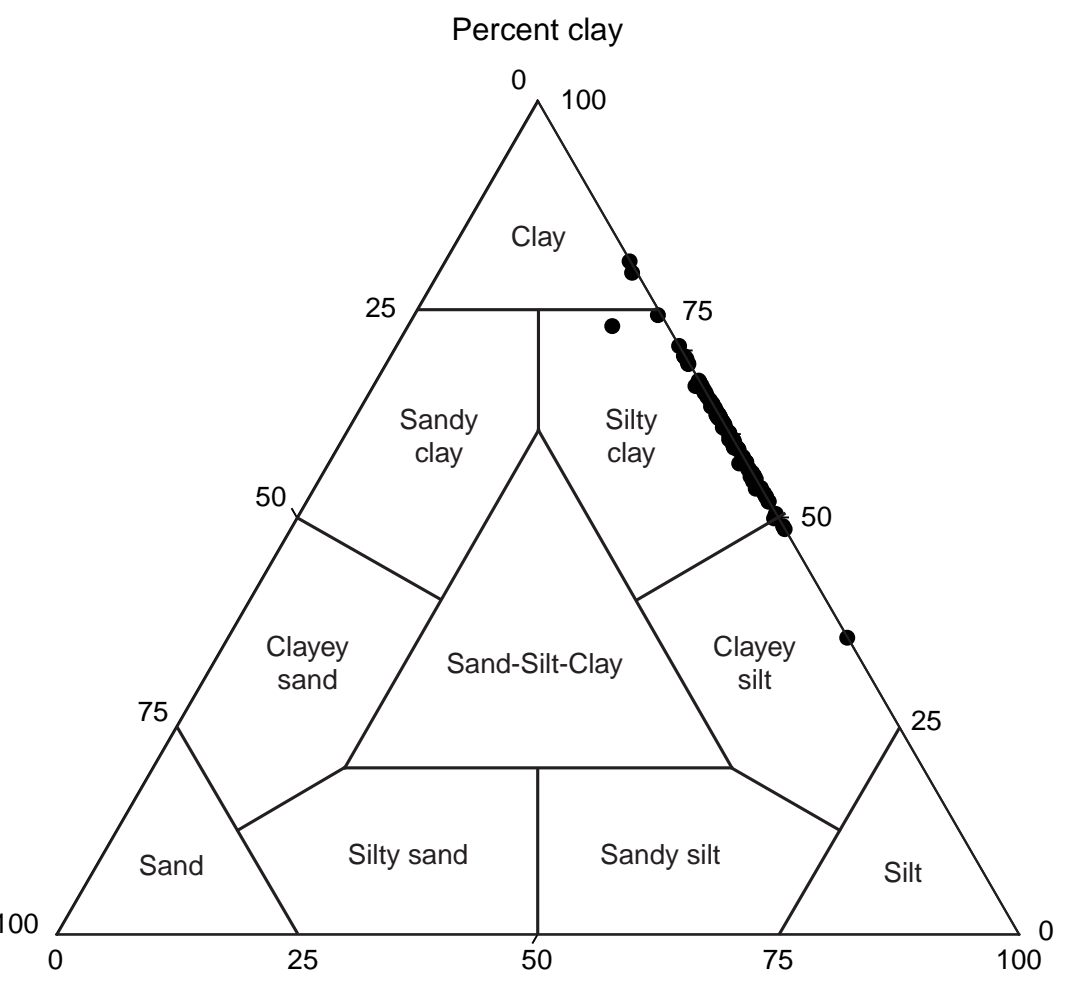

Percent silt

B

Percent sand

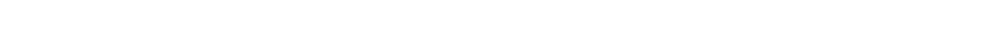

Percent silt

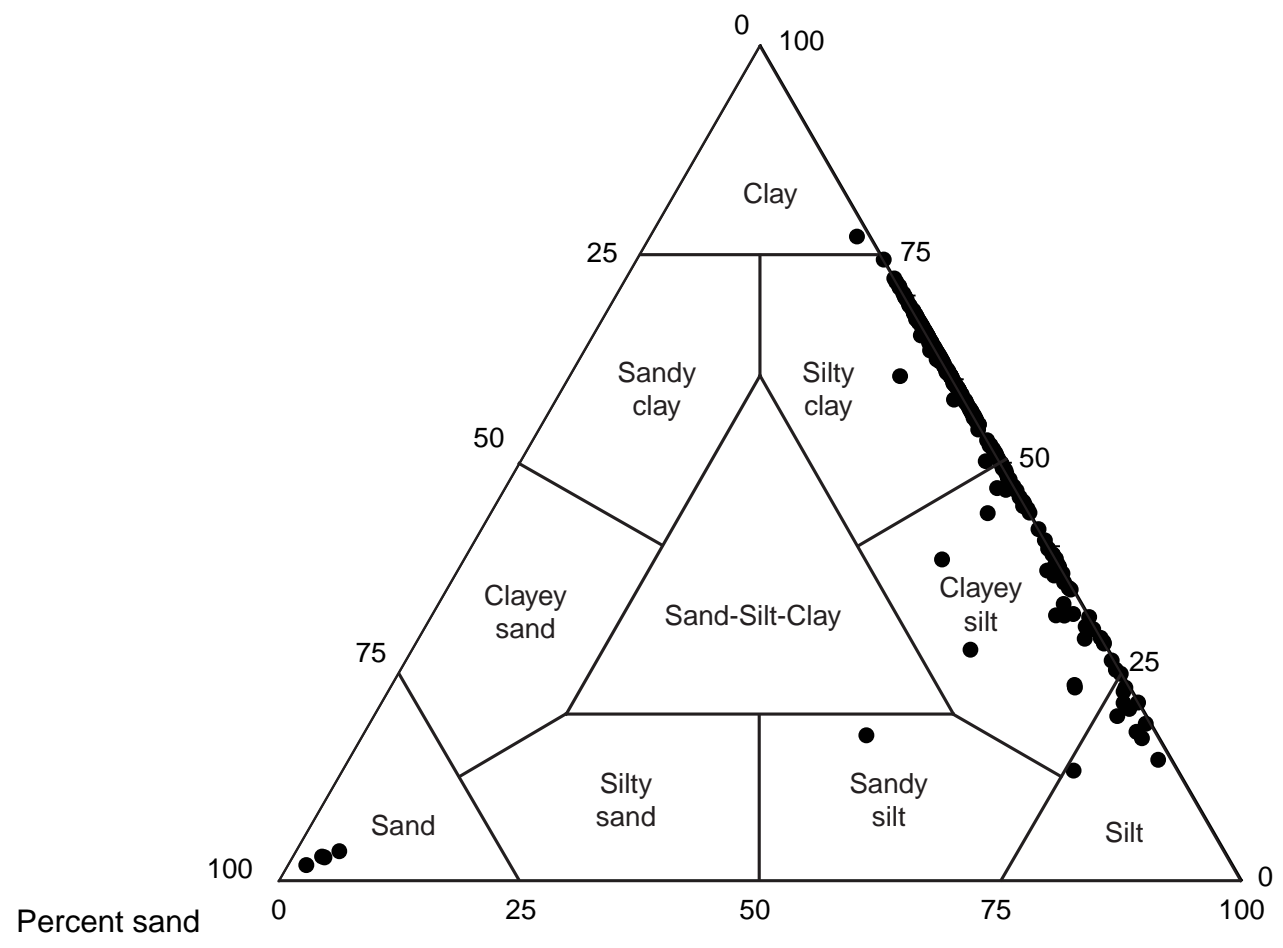

Percent silt 
Figure F10. Particle size distribution plot of three reproducibility runs for Section 308-U1324C-7H-1.

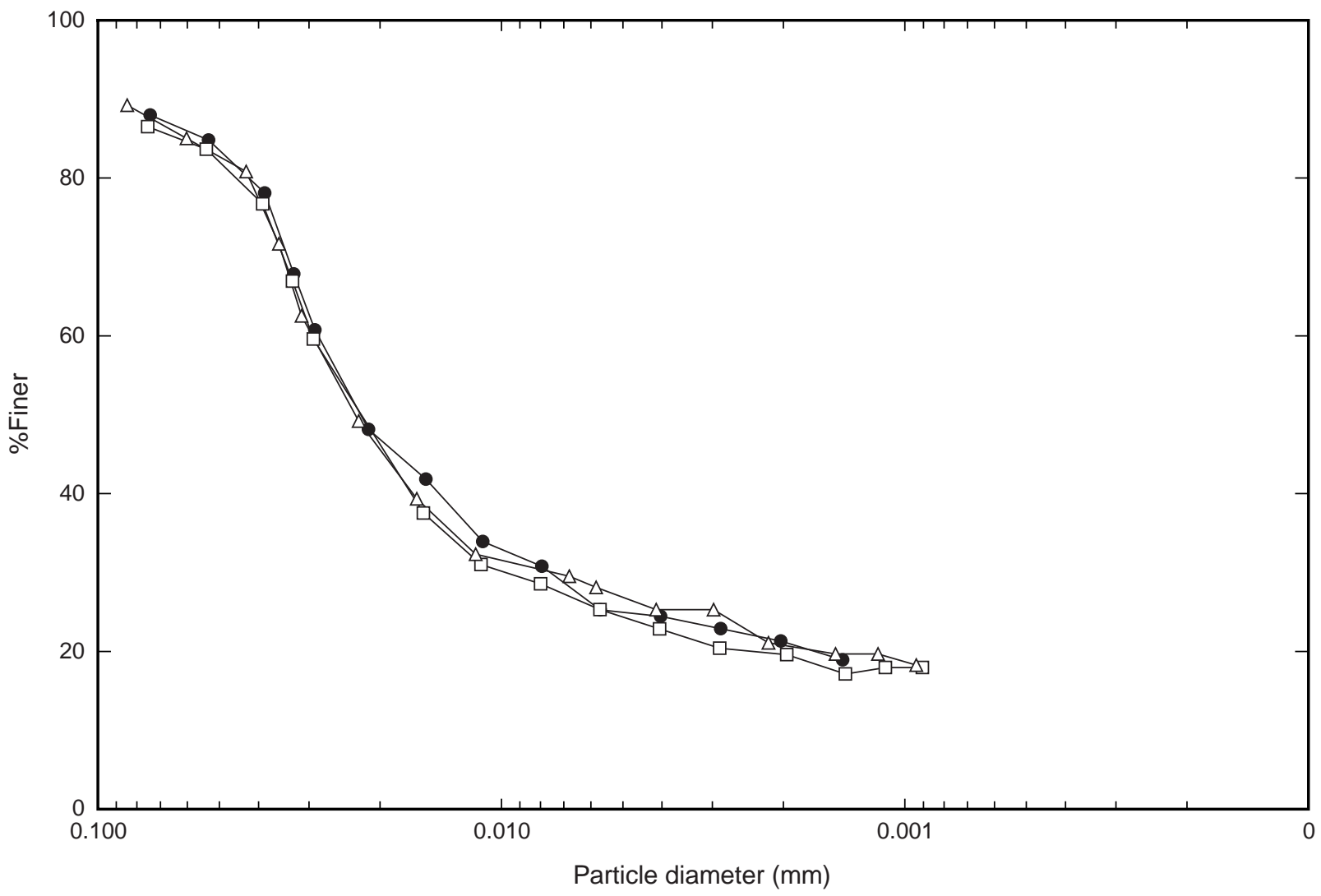


Figure F11. Particle size distribution plot showing results of four experiments on Section 308-U1324C-7H-1, with different initial dry masses.

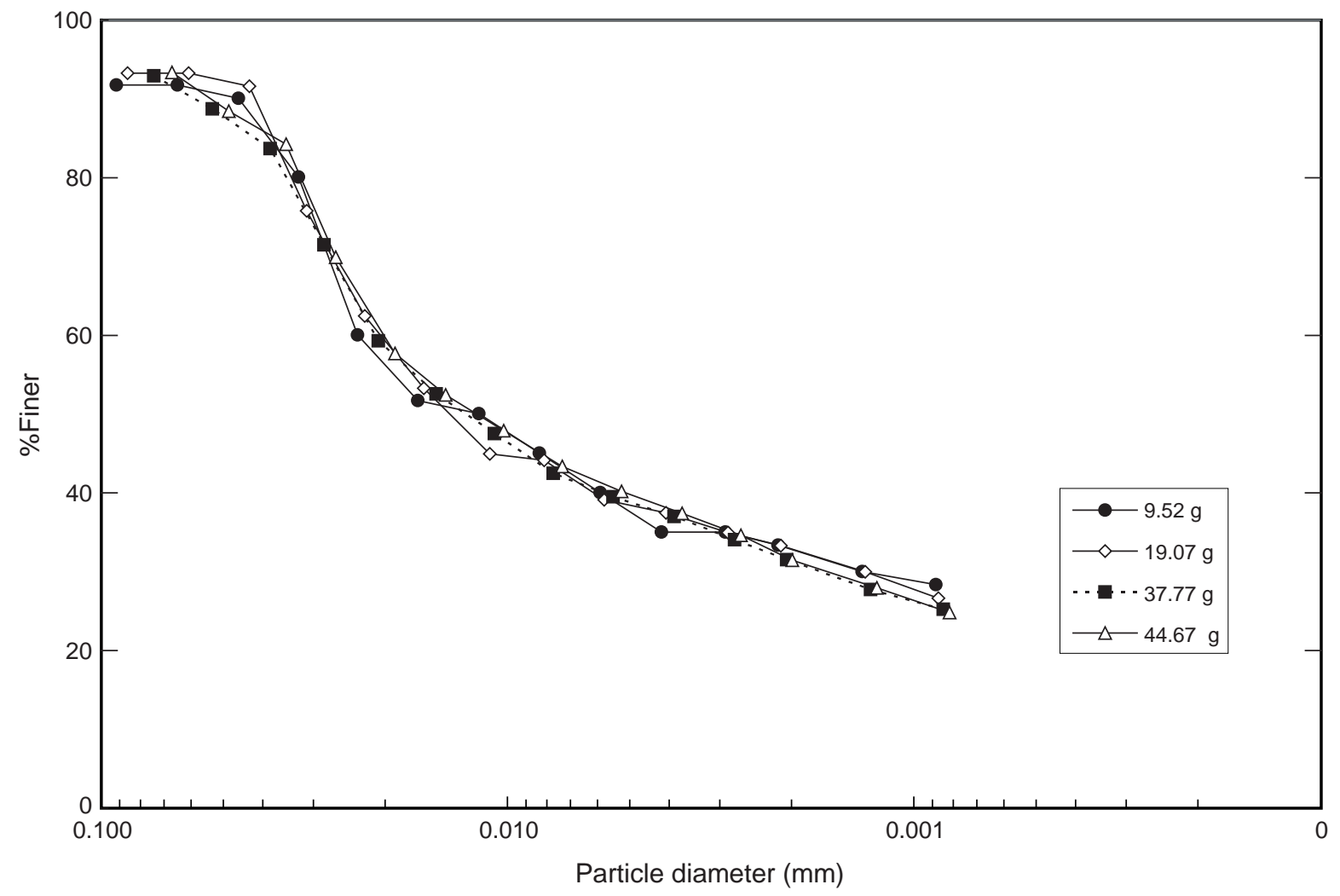


Table T1. Particle size analysis results, Site U1322. (See table note.)

\begin{tabular}{|c|c|c|c|c|c|}
\hline \multirow{2}{*}{$\begin{array}{l}\text { Hole, core, section, } \\
\text { interval }(\mathrm{cm})\end{array}$} & \multirow{2}{*}{$\begin{array}{l}\text { Depth } \\
\text { (mbsf) }\end{array}$} & \multicolumn{3}{|c|}{ Particle size (wt\%) } & \multirow{2}{*}{$\begin{array}{l}\text { Process } \\
\text { site }\end{array}$} \\
\hline & & Sand & Silt & Clay & \\
\hline \multicolumn{6}{|l|}{$308-$} \\
\hline U1322B-1H-1, 60-62 & 0.60 & 5.76 & 21.45 & 72.79 & PSU \\
\hline U1322B-2H-1, 60-62 & 4.60 & 0.07 & 19.39 & 80.54 & PSU \\
\hline U1322B-2H-5, 60-62 & 10.60 & 0.49 & 20.33 & 79.18 & PSU \\
\hline U1322B-3H-2, 60-62 & 15.60 & 0.13 & 41.53 & 58.34 & PSU \\
\hline U1322B-3H-4, 60-62 & 18.60 & 0.10 & 43.35 & 56.55 & PSU \\
\hline U1322B-3H-5, 60-62 & 20.10 & 0.13 & 31.58 & 68.29 & PSU \\
\hline U1322B-4H-2, 60-62 & 25.10 & 0.13 & 44.21 & 55.66 & PSU \\
\hline U1322B-4H-3 & 27.17 & 0.40 & 34.10 & 65.50 & MIT \\
\hline U1322B-4H-5, 60-62 & 29.60 & 0.07 & 41.77 & 58.16 & PSU \\
\hline U1322B-5H-2, 60-62 & 34.60 & 0.13 & 31.63 & 68.24 & PSU \\
\hline U1322B-5H-6, 60-62 & 40.60 & 0.05 & 34.35 & 65.60 & PSU \\
\hline U1322B-6H-3, 60-62 & 45.36 & 0.05 & 64.54 & 35.41 & PSU \\
\hline U1322B-6H-4, 60-62 & 46.36 & 0.15 & 33.76 & 66.09 & PSU \\
\hline U1322B-6H-5, 60-62 & 47.86 & 0.06 & 30.89 & 69.05 & PSU \\
\hline U1322B-6H-6, 60-62 & 49.36 & 0.11 & 30.68 & 69.21 & PSU \\
\hline U1322B-6H-7, 60-62 & 50.36 & 0.04 & 39.04 & 60.92 & PSU \\
\hline U1322B-7H-1, 60-62 & 52.10 & 0.17 & 35.03 & 64.80 & PSU \\
\hline U1322B-7H-2, 60-62 & 53.60 & 0.12 & 35.54 & 64.34 & PSU \\
\hline U1322B-7H-3, 60-62 & 55.10 & 0.03 & 36.61 & 63.36 & PSU \\
\hline U1322B-7H-4, 60-62 & 56.60 & 0.11 & 35.02 & 64.87 & PSU \\
\hline U1322B-7H-5, 60-62 & 58.10 & 0.08 & 36.66 & 63.26 & PSU \\
\hline U1322B-7H-6, 60-62 & 59.60 & 0.03 & 37.92 & 62.05 & PSU \\
\hline U1322B-8H-1, 60-62 & 61.60 & 0.05 & 38.62 & 61.33 & PSU \\
\hline U1322B-8H-2, 60-62 & 63.10 & 0.01 & 38.24 & 61.75 & PSU \\
\hline U1322B-8H-3, 60-62 & 64.60 & 0.02 & 37.76 & 62.22 & PSU \\
\hline U1322B-8H-4, 60-62 & 66.10 & 0.02 & 38.01 & 61.97 & PSU \\
\hline U1322B-8H-5, 60-62 & 67.60 & 0.02 & 31.12 & 68.86 & PSU \\
\hline U1322B-8H-6, 60-62 & 69.10 & 0.01 & 38.12 & 61.87 & PSU \\
\hline U1322B-9H-1, 60-62 & 71.10 & 0.02 & 46.63 & 53.35 & PSU \\
\hline U1322D-2H-2 & 72.00 & 0.00 & 41.00 & 59.00 & MIT \\
\hline U1322D-2H-2 & 72.00 & 0.40 & 41.40 & 58.20 & MIT \\
\hline U1322B-9H-2, 60-62 & 72.60 & 0.02 & 38.65 & 61.33 & PSU \\
\hline U1322B-9H-4, 60-62 & 75.60 & 0.03 & 45.20 & 54.77 & PSU \\
\hline U1322B-1H-1, 60-62 & 80.60 & 0.02 & 40.77 & 59.21 & PSU \\
\hline U1322B-1H-2, 60-62 & 82.10 & 0.02 & 39.98 & 60.00 & PSU \\
\hline U1322B-1H-5, 60-62 & 86.60 & 0.41 & 40.38 & 59.21 & PSU \\
\hline U1322B-11H-1, 60-62 & 90.10 & 0.02 & 43.49 & 56.49 & PSU \\
\hline U1322B-11H-3, 60-62 & 91.61 & 0.03 & 36.48 & 63.49 & PSU \\
\hline U1322B-11H-5, 60-62 & 93.70 & 0.02 & 51.20 & 48.78 & PSU \\
\hline U1322B-11H-6, 60-62 & 95.20 & 0.03 & 40.01 & 59.96 & PSU \\
\hline U1322B-11H-7, 60-62 & 96.70 & 0.02 & 47.63 & 52.35 & PSU \\
\hline U1322B-12H-1, 59-61 & 99.59 & 0.03 & 47.65 & 52.32 & PSU \\
\hline U1322B-12H-2, 59-61 & 101.09 & 0.05 & 41.90 & 58.05 & PSU \\
\hline U1322B-12H-3, 59-61 & 102.59 & 0.01 & 45.21 & 54.78 & PSU \\
\hline U1322D-3H-3, 42-46 & 103.44 & 0.07 & 48.21 & 51.72 & PSU \\
\hline U1322B-12H-4, 59-61 & 104.09 & 0.02 & 48.21 & 51.77 & PSU \\
\hline U1322B-12H-5, 59-61 & 105.59 & 0.02 & 37.85 & 62.13 & PSU \\
\hline
\end{tabular}

\begin{tabular}{|c|c|c|c|c|c|}
\hline \multirow{2}{*}{$\begin{array}{l}\text { Hole, core, section, } \\
\text { interval }(\mathrm{cm})\end{array}$} & \multirow{2}{*}{$\begin{array}{l}\text { Depth } \\
\text { (mbsf) }\end{array}$} & \multicolumn{3}{|c|}{ Particle size (wt\%) } & \multirow{2}{*}{$\begin{array}{l}\text { Process } \\
\text { site }\end{array}$} \\
\hline & & Sand & Silt & Clay & \\
\hline U1322B-12H-6, 59-61 & 107.09 & 0.01 & 43.54 & 56.45 & PSU \\
\hline U1322B-12H-7, 59-61 & 108.09 & 0.03 & 49.70 & 50.27 & PSU \\
\hline U1322B-13H-1, 59-61 & 109.09 & 0.02 & 51.53 & 48.45 & PSU \\
\hline U1322B-13H-3, 59-61 & 111.92 & 0.02 & 47.25 & 52.73 & PSU \\
\hline U1322B-13H-4, 59-61 & 113.42 & 0.02 & 45.54 & 54.44 & PSU \\
\hline U1322B-14H-1, 60-62 & 116.90 & 0.02 & 42.91 & 57.07 & PSU \\
\hline U1322B-14H-3, 60-62 & 119.90 & 0.36 & 25.55 & 74.09 & PSU \\
\hline U1322B-14H-4, 60-62 & 121.40 & 0.01 & 45.15 & 54.84 & PSU \\
\hline U1322B-14H-5, 60-62 & 122.90 & 0.02 & 37.07 & 62.91 & PSU \\
\hline U1322B-15H-1, 60-62 & 125.40 & 0.13 & 39.20 & 60.67 & PSU \\
\hline U1322B-15H-1 & 125.80 & 0.00 & 29.60 & 70.40 & MIT \\
\hline U1322B-15H-2, 59-61 & 126.89 & 0.07 & 33.85 & 66.08 & PSU \\
\hline U1322B-15H-3, 59-61 & 128.39 & 0.08 & 34.85 & 65.07 & PSU \\
\hline U1322B-15H-4, 60-62 & 129.90 & 0.07 & 42.00 & 57.93 & PSU \\
\hline U1322B-16H-1, 59-62 & 134.89 & 0.04 & 43.50 & 56.46 & PSU \\
\hline U1322B-16H-4, 55-58 & 139.35 & 0.05 & 37.46 & 62.49 & PSU \\
\hline U1322B-17H-3, 60-62 & 144.53 & 0.06 & 39.82 & 60.12 & PSU \\
\hline U1322B-17H-4, 60-62 & 145.35 & 0.07 & 40.16 & 59.77 & PSU \\
\hline U1322B-18H-1, 60-62 & 150.50 & 0.21 & 44.17 & 55.62 & PSU \\
\hline U1322B-18H-2, 60-62 & 152.00 & 0.50 & 49.80 & 49.70 & PSU \\
\hline U1322B-18H-3, 60-62 & 153.50 & 0.44 & 45.40 & 54.16 & PSU \\
\hline U1322B-18H-4, 61-63 & 155.01 & 0.25 & 38.01 & 61.74 & PSU \\
\hline U1322B-18H-5, 60-62 & 156.50 & 0.19 & 40.27 & 59.54 & PSU \\
\hline U1322B-18H-6 & 158.01 & 0.70 & & & MIT \\
\hline U1322B-19H-2, 60-62 & 159.90 & 0.31 & 43.22 & 56.47 & PSU \\
\hline U1322B-19H-5, 60-62 & 164.40 & 0.09 & & 61.71 & PSU \\
\hline U1322B-2H-1, 66-68 & 167.36 & 0.42 & 44.83 & 54.75 & PSU \\
\hline U1322B-2H-2, 60-62 & 168.80 & 0.81 & 42.88 & 56.31 & PSU \\
\hline U1322B-21H-1, 60-62 & 175.10 & 0.14 & 39.45 & 60.41 & PSU \\
\hline U1322B-21H-4, 60-62 & 179.60 & 0.18 & 43.10 & 56.72 & PSU \\
\hline U1322B-22H-1, 60-62 & 182.90 & 0.07 & 38.70 & 61.23 & PSU \\
\hline U1322B-22H-2, 60-62 & 184.40 & 0.07 & 37.48 & 62.45 & PSU \\
\hline U1322B-23H-1, 60-62 & 189.60 & 0.16 & 40.78 & 59.06 & PSU \\
\hline U1322B-23H-6, 60-62 & 197.10 & 0.31 & 36.56 & 63.13 & PSU \\
\hline U1322B-24H-1, 59-61 & 199.09 & 0.26 & 37.56 & 62.18 & PSU \\
\hline U1322B-24H-2, 59-61 & 200.59 & 0.62 & 46.10 & 53.28 & PSU \\
\hline U1322B-25H-1, 60-62 & 202.30 & 0.35 & 41.17 & 58.48 & PSU \\
\hline U1322B-25H-5, 60-62 & 207.65 & 0.06 & 35.20 & 64.74 & PSU \\
\hline U1322B-25H-6, 60-62 & 209.13 & 0.03 & 38.88 & 61.09 & PSU \\
\hline U1322B-26H-1, 59-61 & 210.89 & 0.02 & 39.00 & 60.98 & PSU \\
\hline U1322B-27H-1, 58-62 & 214.68 & 0.03 & 44.76 & 55.21 & PSU \\
\hline U1322B-27H-2, 58-62 & 216.18 & 0.24 & 41.20 & 58.56 & PSU \\
\hline U1322B-27H-4, 58-62 & 219.18 & 0.36 & 39.01 & 60.63 & PSU \\
\hline U1322B-28H-2, 60-62 & 222.40 & 0.26 & 37.71 & 62.03 & PSU \\
\hline U1322B-29H-3, 60-62 & 230.70 & 0.05 & 33.97 & 65.98 & PSU \\
\hline U1322B-29H-4, 60-62 & 232.20 & 0.07 & 36.05 & 63.88 & PSU \\
\hline U1322B-29H-5, 60-62 & 233.70 & 0.04 & 33.71 & 66.25 & PSU \\
\hline
\end{tabular}

Note: PSU = the Pennsylvania State University, MIT = Massachusetts Institute of Technology. 
Table T2. Particle size analysis results, Site U1324. (See table note.) (Continued on next page.)

\begin{tabular}{|c|c|c|c|c|c|c|c|c|c|c|c|}
\hline \multirow{2}{*}{$\begin{array}{l}\text { Hole, core, section, } \\
\text { interval }(\mathrm{cm})\end{array}$} & \multirow{2}{*}{$\begin{array}{l}\text { Depth } \\
\text { (mbsf) }\end{array}$} & \multicolumn{3}{|c|}{ Particle size (wt\%) } & \multirow{2}{*}{$\begin{array}{l}\text { Process } \\
\text { site }\end{array}$} & \multirow{2}{*}{$\begin{array}{l}\text { Hole, core, section, } \\
\text { interval }(\mathrm{cm})\end{array}$} & \multirow{2}{*}{$\begin{array}{l}\text { Depth } \\
\text { (mbsf) }\end{array}$} & \multicolumn{3}{|c|}{ Particle size (wt\%) } & \multirow{2}{*}{$\begin{array}{c}\text { Process } \\
\text { site }\end{array}$} \\
\hline & & Sand & Silt & Clay & & & & Sand & Silt & Clay & \\
\hline 308- & & & & & & U1324B-16H-4, 60-62 & 140.33 & 0.01 & 42.73 & 57.26 & PSU \\
\hline U1324B-1H-1, 60-64 & 0.60 & 1.43 & 21.66 & 76.91 & PSU & U1324B-16H-5, 60-62 & 141.83 & 0.01 & 34.59 & 65.40 & PSU \\
\hline U1324B-1H-2, 60-64 & 2.10 & 0.06 & 35.18 & 64.76 & PSU & U1324B-16H-5, 5-10 & 142.10 & 1.10 & 41.50 & 57.40 & MIT \\
\hline U1324B-2H-3, 60-65 & 7.40 & 0.16 & 42.33 & 57.51 & PSU & U1324B-16H-5, 5-10 & 142.10 & 0.00 & 42.00 & 58.00 & MIT \\
\hline U1324B-2H-5, 60-65 & 10.40 & 0.40 & 45.81 & 53.79 & PSU & U1324B-16H-5, 5-10 & 142.10 & 0.00 & 37.70 & 62.30 & MIT \\
\hline U1324B-2H-6, 60-65 & 11.90 & 0.16 & 37.35 & 62.49 & PSU & U1324B-16H-6, 60-62 & 143.33 & 0.01 & 50.19 & 49.80 & PSU \\
\hline U1324B-2H-6, 128-130 & 12.58 & 0.25 & 63.16 & 36.59 & PSU & U1324B-16H-7, 60-62 & 144.33 & 0.02 & 41.30 & 58.68 & PSU \\
\hline U1324B-3H-1, 60-65 & 13.90 & 0.18 & 40.41 & 59.41 & PSU & U1324B-17H-1, 60-62 & 145.50 & 0.01 & 37.39 & 62.60 & PSU \\
\hline U1324B-3H-2, 60-65 & 15.40 & 0.23 & 39.03 & 60.74 & PSU & U1324B-17H-2, 60-62 & 147.00 & 0.04 & 37.96 & 62.00 & PSU \\
\hline U1324B-3H-3, 61-66 & 16.91 & 0.14 & 42.35 & 57.51 & PSU & U1324B-17H-3, 60-62 & 148.50 & 0.04 & 38.46 & 61.50 & PSU \\
\hline U1324B-3H-4, 60-65 & 18.40 & 0.11 & 36.59 & 63.30 & PSU & U1324B-17H-4, 60-62 & 150.00 & 0.01 & 48.79 & 51.20 & PSU \\
\hline U1324B-3H-4, 114-116 & 18.94 & 0.11 & 52.06 & 47.83 & PSU & U1324B-17H-5, 60-62 & 151.50 & 0.01 & 44.39 & 55.60 & PSU \\
\hline U1324B-3H-5, 59-64 & 19.89 & 0.04 & 32.05 & 67.91 & PSU & U1324B-17H-6, 60-62 & 153.00 & 0.02 & 56.13 & 43.85 & PSU \\
\hline U1324B-3H-6, 59-64 & 21.39 & 0.07 & 30.24 & 69.69 & PSU & U1324B-18H-1, 60-62 & 154.30 & 0.02 & 44.98 & 55.00 & PSU \\
\hline U1324B-4H-1, 58-63 & 23.38 & 0.08 & 41.65 & 58.27 & PSU & U1324B-18H-2, 60-62 & 155.80 & 0.03 & 41.47 & 58.50 & PSU \\
\hline U1324B-4H-5, 59-64 & 29.39 & 0.03 & 36.90 & 63.07 & PSU & U1324B-18H-3, 59-61 & 157.29 & 0.05 & 39.45 & 60.50 & PSU \\
\hline U1324B-4H-7 & 31.86 & 0.00 & 44.50 & 55.50 & MIT & U1324B-18H-4, 60-62 & 158.80 & 0.01 & 39.24 & 60.75 & PSU \\
\hline U1324B-4H-7 & 32.10 & 0.00 & 44.70 & 55.30 & MIT & U1324B-18H-5, 60-62 & 160.30 & 0.00 & 48.50 & 51.50 & MIT \\
\hline U1324B-4H-7 & 32.14 & 0.70 & 34.20 & 65.10 & MIT & U1324B-19H-1, 60-62 & 162.60 & 0.04 & 40.06 & 59.90 & PSU \\
\hline U1324B-5H-2, 59-63 & 34.39 & 0.06 & 39.84 & 60.10 & PSU & U1324B-19H-2, 60-62 & 164.10 & 0.10 & 36.17 & 63.73 & PSU \\
\hline U1324B-5H-5, 59-63 & 38.89 & 0.14 & 38.68 & 61.18 & PSU & U1324B-19H-3, 60-62 & 165.60 & 0.15 & 33.25 & 66.60 & PSU \\
\hline U1324B-5H-6, 59-63 & 40.39 & 0.02 & 32.54 & 67.44 & PSU & U1324B-19H-4, 60-62 & 167.10 & 0.22 & 35.03 & 64.75 & PSU \\
\hline U1324B-6H-1, 60-62 & 42.40 & 0.04 & 30.60 & 69.36 & PSU & U1324B-19H-5, 60-62 & 168.60 & 0.02 & 33.78 & 66.20 & PSU \\
\hline U1324B-6H-5, 60-62 & 48.40 & 0.24 & 32.73 & 67.03 & PSU & U1324B-19H-1, 60-62 & 170.10 & 0.02 & 35.48 & 64.50 & PSU \\
\hline U1324C-1H-1 & 51.10 & 0.00 & 31.90 & 68.10 & MIT & U1324B-20H-1, 60-62 & 171.40 & 0.02 & 36.28 & 63.70 & PSU \\
\hline U1324C-1H-1 & 51.10 & 0.00 & 34.60 & 65.40 & MIT & U1324B-20H-2, 60-62 & 172.90 & 0.04 & 34.64 & 65.32 & PSU \\
\hline U1324C-1H-1-1 & 51.14 & 0.04 & 42.59 & 57.37 & PSU & U1324B-20H-3, 60-62 & 174.40 & 0.01 & 32.39 & 67.60 & PSU \\
\hline U1324C-1H-1-2 & 51.21 & 0.01 & 44.10 & 55.89 & PSU & U1324B-20H-4, 60-62 & 175.90 & 0.03 & 30.24 & 69.73 & PSU \\
\hline U1324B-7H-2, 60-62 & 53.40 & 0.03 & 34.26 & 65.71 & PSU & U1324B-20H-5, 60-62 & 177.40 & 0.03 & 39.70 & 60.27 & PSU \\
\hline U1324B-7H-6, 60-62 & 59.41 & 0.07 & 42.86 & 57.07 & PSU & U1324B-21H-1, 60-62 & 179.60 & 0.01 & 35.84 & 64.15 & PSU \\
\hline U1324B-7H-7, 5-9 & 60.31 & 0.00 & 42.80 & 57.20 & MIT & U1324B-21H-3, 112-116 & 183.14 & 0.31 & 55.04 & 44.65 & PSU \\
\hline U1324B-7H-7, 5-9 & 60.31 & 0.00 & 39.00 & 61.00 & MIT & U1324B-21H-5, 60-62 & 185.60 & 0.02 & 38.10 & 61.88 & PSU \\
\hline U1324B-7H-7, 5-9 & 60.31 & 0.10 & 36.20 & 63.70 & MIT & U1324B-22H-3, 60-62 & 190.50 & 0.02 & 37.23 & 62.75 & PSU \\
\hline U1324B-7H-7 & 60.62 & 0.00 & 50.40 & 49.60 & MIT & U1324B-23H-1, 60-62 & 194.40 & 0.12 & 40.79 & 59.09 & PSU \\
\hline U1324B-8H-3, 60-62 & 64.40 & 0.13 & 54.16 & 45.71 & PSU & U1324B-23H-5 & 199.80 & 0.50 & 37.30 & 62.20 & MIT \\
\hline U1324B-9H-1, 61-63 & 70.91 & 0.03 & 40.57 & 59.40 & PSU & U1324B-24H-1, 60-62 & 201.00 & 0.05 & 28.05 & 71.90 & PSU \\
\hline U1324B-9H-4, 60-62 & 75.40 & 0.14 & 35.17 & 64.69 & PSU & U1324B-24H-3, 60-62 & 204.00 & 0.02 & 35.78 & 64.20 & PSU \\
\hline U1324B-9H-6, 60-62 & 78.40 & 0.01 & 34.34 & 65.65 & PSU & U1324B-25H-1, 60-62 & 208.10 & 0.09 & 31.31 & 68.60 & PSU \\
\hline U1324B-1H-1, 60-62 & 80.40 & 0.02 & 33.17 & 66.81 & PSU & U1324B-25H-5, 60-62 & 214.10 & 0.06 & 34.14 & 65.80 & PSU \\
\hline U1324B-1H-5, 60-62 & 86.40 & 0.03 & 38.09 & 61.88 & PSU & U1324B-26H-3, 60-62 & 219.70 & 0.17 & 36.26 & 63.57 & PSU \\
\hline U1324B-1H-7 & 88.80 & 0.00 & 39.70 & 60.30 & MIT & U1324B-26H-3 & 220.34 & 0.00 & 34.00 & 66.00 & MIT \\
\hline U1324B-11H-2, 60-62 & 91.40 & 0.02 & 34.51 & 65.47 & PSU & U1324B-26H-4, 60-62 & 221.20 & 0.04 & 36.56 & 63.40 & PSU \\
\hline U1324B-11H-4, 60-62 & 94.40 & 0.01 & 43.68 & 56.31 & PSU & U1324B-26H-5, 60-62 & 222.20 & 0.08 & 35.32 & 64.60 & PSU \\
\hline U1324B-12H-1, 60-62 & 99.40 & 0.03 & 49.63 & 50.34 & PSU & U1324B-27H-4, 60-62 & 227.60 & 0.08 & 37.96 & 61.96 & PSU \\
\hline U1324C-2H-2 & 104.50 & 0.00 & 49.20 & 50.80 & MIT & U1324B-28H-4, 60-62 & 234.22 & 0.08 & 32.94 & 66.98 & PSU \\
\hline U1324B-12H-5, 60-62 & 105.40 & 0.02 & 39.73 & 60.25 & PSU & U1324B-29H-2, 60-62 & 240.70 & 0.01 & 29.89 & 70.10 & PSU \\
\hline U1324B-13H-1, 60-62 & 108.90 & 0.01 & 51.06 & 48.93 & PSU & U1324B-29H-5, 60-62 & 245.20 & 0.02 & 34.28 & 65.70 & PSU \\
\hline U1324B-13H-2, 60-62 & 110.40 & 0.06 & 41.76 & 58.18 & PSU & U1324B-29H-6, 60-62 & 246.70 & 0.02 & 32.72 & 67.26 & PSU \\
\hline U1324B-13H-3, 60-62 & 111.90 & 0.07 & 36.13 & 63.80 & PSU & U1324B-30H-2, 60-62 & 249.40 & 0.12 & 39.26 & 60.62 & PSU \\
\hline U1324B-13H-4, 60-62 & 113.40 & 0.04 & 39.31 & 60.65 & PSU & U1324B-30H-3, 60-62 & 250.90 & 0.12 & 35.78 & 64.10 & PSU \\
\hline U1324B-13H-5, 60-62 & 114.90 & 0.05 & 37.74 & 62.21 & PSU & U1324B-30H-6, 60-62 & 255.40 & 0.02 & 36.57 & 63.41 & PSU \\
\hline U1324B-13H-6, 60-62 & 116.40 & 0.04 & 39.69 & 60.27 & PSU & U1324B-31H-3, 60-62 & 260.40 & 0.02 & 43.34 & 56.64 & PSU \\
\hline U1324B-13H-7-1 & 117.40 & 0.03 & 40.07 & 59.90 & PSU & U1324B-31H-3, 120-124 & 261.02 & 0.03 & 41.26 & 58.71 & PSU \\
\hline U1324B-14H-1, 60-62 & 118.40 & 0.03 & 45.56 & 54.41 & PSU & U1324B-31H-4, 60-62 & 261.90 & 0.01 & 28.99 & 71.00 & PSU \\
\hline U1324B-14H-2, 60-62 & 119.36 & 0.02 & 55.02 & 44.96 & PSU & U1324B-31H-5, 60-62 & 263.40 & 0.01 & 43.89 & 56.10 & PSU \\
\hline U1324B-14H-3, 60-62 & 120.22 & 0.02 & 55.68 & 44.30 & PSU & U1324B-32H-4, 60-62 & 269.70 & 0.03 & 35.01 & 64.96 & PSU \\
\hline U1324B-14H-4, 60-62 & 121.52 & 0.03 & 34.97 & 65.00 & PSU & U1324B-33H-2, 60-62 & 275.74 & 0.03 & 35.18 & 64.79 & PSU \\
\hline U1324B-14H-5, 60-62 & 122.25 & 0.03 & 36.88 & 63.09 & PSU & U1324B-33H-5, 60-62 & 280.20 & 0.02 & 37.75 & 62.23 & PSU \\
\hline U1324B-14H-6, 60-62 & 123.74 & 0.05 & 41.37 & 58.58 & PSU & U1324B-34H-2, 60-62 & 284.60 & 0.02 & 33.78 & 66.20 & PSU \\
\hline U1324B-14H-7, 60-62 & 125.25 & 0.02 & 54.80 & 45.18 & PSU & U1324B-34H-3, 60-62 & 286.10 & 0.04 & 29.16 & 70.80 & PSU \\
\hline U1324B-15H-1, 60-62 & 127.90 & 0.08 & 39.20 & 60.72 & PSU & U1324B-34H-5, 60-62 & 289.10 & 0.02 & 36.98 & 63.00 & PSU \\
\hline U1324B-15H-2, 60-62 & 129.40 & 0.02 & 33.42 & 66.56 & PSU & U1324B-35H-2, 60-62 & 292.50 & 0.03 & 33.36 & 66.61 & PSU \\
\hline U1324B-15H-3, 60-62 & 130.90 & 0.05 & 28.45 & 71.50 & PSU & U1324B-35H-3, 60-62 & 294.00 & 0.01 & 37.61 & 62.38 & PSU \\
\hline U1324B-15H-4, 60-62 & 132.40 & 0.04 & 39.30 & 60.66 & PSU & U1324B-36H-1, 60-62 & 297.00 & 0.03 & 33.07 & 66.90 & PSU \\
\hline U1324B-15H-5, 60-62 & 133.90 & 0.01 & 45.54 & 54.45 & PSU & U1324B-36H-2, 60-62 & 298.50 & 0.03 & 36.67 & 63.30 & PSU \\
\hline U1324B-15H-5 & 134.20 & 0.30 & 37.70 & 62.00 & MIT & U1324B-36H-3, 60-62 & 300.00 & 0.18 & 40.53 & 59.29 & PSU \\
\hline U1324B-16H-2, 60-62 & 138.40 & 0.01 & 44.49 & 55.50 & PSU & U1324B-36H-5, 60-62 & 303.00 & 0.05 & 37.95 & 62.00 & PSU \\
\hline U1324B-16H-3, 60-62 & 139.40 & 0.01 & 44.06 & 55.93 & PSU & U1324C-6H-3-1 & 303.94 & 0.03 & 36.37 & 63.60 & PSU \\
\hline
\end{tabular}


Table T2 (continued).

\begin{tabular}{|c|c|c|c|c|c|}
\hline \multirow{2}{*}{$\begin{array}{l}\text { Hole, core, section, } \\
\text { interval }(\mathrm{cm})\end{array}$} & \multirow{2}{*}{$\begin{array}{l}\text { Depth } \\
\text { (mbsf) }\end{array}$} & \multicolumn{3}{|c|}{ Particle size (wt\%) } & \multirow{2}{*}{$\begin{array}{l}\text { Process } \\
\text { site }\end{array}$} \\
\hline & & Sand & Silt & Clay & \\
\hline U1324C-6H-3-2 & 304.02 & 0.11 & 37.09 & 62.80 & PSU \\
\hline U1324B-37H-1, 10-12 & 305.70 & 91.99 & 4.69 & 3.32 & PSU \\
\hline U1324B-37H-1, 18-20 & 305.78 & 93.90 & 3.52 & 2.58 & PSU \\
\hline U1324B-37H-1, 110-112 & 306.70 & 94.12 & 3.21 & 2.67 & PSU \\
\hline U1324B-37H-3, 60-63 & 309.20 & 0.64 & 36.06 & 63.30 & PSU \\
\hline U1324B-38H-1, 10-12 & 311.40 & 96.27 & 2.09 & 1.64 & PSU \\
\hline U1324B-38H-1, 60-62 & 311.90 & 0.28 & 35.52 & 64.20 & PSU \\
\hline U1324B-38H-2, 60-62 & 313.40 & 0.03 & 34.87 & 65.10 & PSU \\
\hline U1324B-39H-3, 60-62 & 322.80 & 0.05 & 41.67 & 58.28 & PSU \\
\hline U1324B-39H-4, 60-62 & 324.30 & 0.04 & 35.66 & 64.30 & PSU \\
\hline U1324B-40H-1, 60-62 & 328.20 & 0.21 & 36.24 & 63.55 & PSU \\
\hline U1324B-40H-4, 60-62 & 332.70 & 0.12 & 32.98 & 66.90 & PSU \\
\hline U1324B-41H-3, 63-65 & 337.13 & 0.11 & 32.18 & 67.71 & PSU \\
\hline U1324B-42H-1, 59-61 & 339.59 & 0.02 & 34.77 & 65.21 & PSU \\
\hline U1324B-42H-3, 58-60 & 342.58 & 0.01 & 34.99 & 65.00 & PSU \\
\hline U1324B-43H-2, 59-61 & 347.09 & 0.02 & 31.98 & 68.00 & PSU \\
\hline U1324B-45X-2, 60-62 & 360.00 & 0.02 & 35.34 & 64.64 & PSU \\
\hline U1324B-46X-2, 109-110 & 364.99 & 0.09 & 59.37 & 40.54 & PSU \\
\hline U1324B-46X-3, 60-62 & 366.00 & 0.15 & 60.98 & 38.87 & PSU \\
\hline U1324B-47H-2, 60-62 & 370.10 & 0.46 & 64.70 & 34.84 & PSU \\
\hline U1324B-47H-3, 60-62 & 371.60 & 1.23 & 62.42 & 36.35 & PSU \\
\hline U1324B-47H-4, 64-66 & 372.62 & 11.91 & 49.83 & 38.26 & PSU \\
\hline U1324B-48H-1, 60-62 & 373.80 & 1.95 & 65.14 & 32.91 & PSU \\
\hline U1324B-48H-3, 60-62 & 376.80 & 1.10 & 52.30 & 46.60 & MIT \\
\hline U1324B-48H-4, 60-62 & 378.30 & 0.05 & 32.95 & 67.00 & PSU \\
\hline U1324B-48H-5, 60-62 & 379.80 & 14.37 & 58.19 & 27.44 & PSU \\
\hline U1324B-48H-6, 60-62 & 380.80 & 1.93 & 51.27 & 46.80 & PSU \\
\hline U1324B-49H-2, 60-62 & 383.60 & 0.03 & 42.97 & 57.00 & PSU \\
\hline U1324B-49H-4, 60-62 & 386.51 & 1.84 & 69.39 & 28.77 & PSU \\
\hline U1324B-50H-2, 60-62 & 390.00 & 0.13 & 71.69 & 28.18 & PSU \\
\hline U1324B-50H-3, 27-29 & 391.17 & 3.11 & 77.42 & 19.47 & PSU \\
\hline U1324B-50H-4, 60-62 & 393.00 & 0.00 & 49.00 & 51.00 & MIT \\
\hline U1324B-50H-5, 57-59 & 393.97 & 0.09 & 58.02 & 41.89 & PSU \\
\hline U1324B-51X-1, 60-62 & 395.10 & 0.15 & 47.94 & 51.91 & PSU \\
\hline U1324B-52X-1, 57-59 & 397.37 & 1.67 & 61.42 & 36.91 & PSU \\
\hline U1324B-52X-2, 60-62 & 398.90 & 1.66 & 77.27 & 21.07 & PSU \\
\hline U1324B-52X-2, 95-97 & 399.25 & 2.05 & 80.34 & 17.61 & PSU \\
\hline U1324B-52X-3, 60-62 & 400.40 & 0.25 & 60.19 & 39.56 & PSU \\
\hline U1324B-52X-4, 60-62 & 401.90 & 0.61 & 63.89 & 35.50 & PSU \\
\hline U1324B-52X-5, 11-13 & 402.91 & 1.01 & 68.77 & 30.22 & PSU \\
\hline U1324C-7H-1-2 & 405.81 & 1.54 & 66.73 & 31.73 & PSU \\
\hline U1324B-53X-1, 72-74 & 407.12 & 3.43 & 65.01 & 31.56 & PSU \\
\hline U1324B-53X-2, 70-72 & 408.60 & 30.30 & 52.50 & 17.20 & MIT \\
\hline U1324B-53X-3, 59-61 & 409.99 & 5.78 & 71.29 & 22.93 & PSU \\
\hline U1324B-53X-4, 64-66 & 411.54 & 2.58 & 65.89 & 31.53 & PSU \\
\hline U1324B-54X-1, 87-89 & 416.87 & 0.22 & 51.81 & 47.97 & PSU \\
\hline U1324B-54X-2, 60-62 & 418.10 & 0.06 & 53.44 & 46.50 & PSU \\
\hline U1324B-54X-3, 60-62 & 419.60 & 0.08 & 51.32 & 48.60 & PSU \\
\hline U1324B-55X-4, 60-62 & 430.80 & 0.03 & 33.68 & 66.29 & PSU \\
\hline U1324B-55X-7, 60-62 & 434.80 & 0.02 & 37.70 & 62.28 & PSU \\
\hline U1324B-56X-4, 60-62 & 440.40 & 0.02 & 25.81 & 74.17 & PSU \\
\hline U1324B-57X-1, 60-62 & 445.60 & 0.08 & 71.53 & 28.39 & PSU \\
\hline U1324B-57X-4, 60-62 & 450.10 & 0.04 & 34.68 & 65.28 & PSU \\
\hline U1324B-58X-1, 60-62 & 455.20 & 0.19 & 62.44 & 37.37 & PSU \\
\hline U1324B-58X-3, 60-62 & 458.20 & 0.08 & 41.97 & 57.95 & PSU \\
\hline U1324B-58X-4, 60-62 & 459.70 & 0.10 & 33.97 & 65.93 & PSU \\
\hline
\end{tabular}

\begin{tabular}{|c|c|c|c|c|c|}
\hline \multirow{2}{*}{$\begin{array}{l}\text { Hole, core, section, } \\
\text { interval }(\mathrm{cm})\end{array}$} & \multirow{2}{*}{$\begin{array}{l}\text { Depth } \\
\text { (mbsf) }\end{array}$} & \multicolumn{3}{|c|}{ Particle size (wt\%) } & \multirow{2}{*}{$\begin{array}{l}\text { Process } \\
\text { site }\end{array}$} \\
\hline & & Sand & Silt & Clay & \\
\hline U1324B-58X-5, 60-62 & 461.24 & 0.10 & 31.12 & 68.78 & PSU \\
\hline U1324B-59X-3, 60-62 & 466.74 & 0.05 & 50.79 & 49.16 & PSU \\
\hline U1324B-59X-5, 60-62 & 469.74 & 0.10 & 68.55 & 31.35 & PSU \\
\hline U1324B-60X-1, 68-70 & 474.58 & 0.05 & 61.60 & 38.35 & PSU \\
\hline U1324B-60X-2-1 & 476.86 & 0.02 & 41.48 & 58.50 & PSU \\
\hline U1324B-60X-2-1 & 476.86 & 0.02 & 41.18 & 58.80 & PSU \\
\hline U1324B-60X-5, 59-61 & 480.49 & 0.03 & 48.02 & 51.95 & PSU \\
\hline U1324B-61X-1, 60-62 & 484.10 & 0.00 & 37.30 & 62.70 & MIT \\
\hline U1324B-61X-2, 60-62 & 485.60 & 0.08 & 39.80 & 60.12 & PSU \\
\hline U1324B-61X-5, 60-62 & 490.10 & 5.30 & 34.50 & 60.20 & MIT \\
\hline U1324B-62X-2, 60-62 & 495.08 & 0.31 & 63.19 & 36.50 & PSU \\
\hline U1324B-62X-5, 61-63 & 499.59 & 0.38 & 69.72 & 29.90 & PSU \\
\hline U1324B-62X-6, 42-44 & 500.90 & 0.98 & 76.60 & 22.42 & PSU \\
\hline U1324B-62X-6, 60-62 & 501.08 & 0.09 & 47.37 & 52.54 & PSU \\
\hline U1324B-62X-CC, 10-12 & 501.49 & 1.86 & 81.30 & 16.84 & PSU \\
\hline U1324B-63X-1, 60-62 & 503.30 & 0.36 & 64.99 & 34.65 & PSU \\
\hline U1324B-63X-2, 60-62 & 504.80 & 0.13 & 78.76 & 21.11 & PSU \\
\hline U1324B-63X-2, 78-80 & 504.98 & 0.04 & 33.36 & 66.60 & PSU \\
\hline U1324B-63X-3, 61-63 & 506.31 & 0.06 & 44.16 & 55.78 & PSU \\
\hline U1324C-8H-2, 32-34 & 506.82 & 0.60 & 80.82 & 18.58 & PSU \\
\hline U1324B-63X-4, 23-25 & 507.43 & 1.40 & 78.24 & 20.36 & PSU \\
\hline U1324B-63X-4, 60-62 & 507.80 & 0.36 & 73.49 & 26.15 & PSU \\
\hline U1324B-63X-4, 139-141 & 508.59 & 0.46 & 74.49 & 25.05 & PSU \\
\hline U1324B-63X-5, 60-62 & 509.34 & 0.20 & 62.09 & 37.71 & PSU \\
\hline U1324C-8H-5, 28-30 & 510.78 & 1.46 & 84.27 & 14.27 & PSU \\
\hline U1324B-64X-1, 60-62 & 513.00 & 0.10 & 49.15 & 50.75 & PSU \\
\hline U1324B-64X-2, 60-62 & 514.00 & 0.10 & 55.17 & 44.73 & PSU \\
\hline U1324B-64X-3, 64-66 & 514.76 & 0.57 & 76.54 & 22.89 & PSU \\
\hline U1324B-64X-4, 33-35 & 515.97 & 0.04 & 43.76 & 56.20 & PSU \\
\hline U1324B-64X-4, 60-62 & 516.29 & 0.18 & 75.26 & 24.56 & PSU \\
\hline U1324B-64X-4, 74-76 & 516.38 & 0.14 & 71.00 & 28.86 & PSU \\
\hline U1324B-65X-1, 60-62 & 522.50 & 0.03 & 44.97 & 55.00 & PSU \\
\hline U1324B-65X-3, 60-62 & 525.50 & 0.14 & 38.41 & 61.45 & PSU \\
\hline U1324B-65X-4, 60-62 & 527.00 & 0.10 & 34.14 & 65.76 & PSU \\
\hline U1324B-65X-5, 60-62 & 528.50 & 0.08 & 45.15 & 54.77 & PSU \\
\hline U1324B-65X-6, 60-62 & 529.50 & 0.10 & 37.65 & 62.25 & PSU \\
\hline U1324B-66X-1, 60-62 & 532.20 & 0.15 & 39.17 & 60.68 & PSU \\
\hline U1324B-67X-1, 53-55 & 541.63 & 0.22 & 39.16 & 60.62 & PSU \\
\hline U1324B-67X-2, 60-62 & 543.20 & 0.03 & 42.69 & 57.28 & PSU \\
\hline U1324B-67X-4, 53-55 & 546.13 & 0.11 & 52.88 & 47.01 & PSU \\
\hline U1324B-67X-4, 60-62 & 546.20 & 0.04 & 40.87 & 59.09 & PSU \\
\hline U1324B-67X-5, 60-62 & 547.22 & 0.11 & 41.77 & 58.12 & PSU \\
\hline U1324B-67X-6, 24-26 & 548.36 & 0.11 & 61.06 & 38.83 & PSU \\
\hline U1324B-67X-6, 60-62 & 548.72 & 0.02 & 39.80 & 60.18 & PSU \\
\hline U1324B-68X-1, 60-62 & 551.30 & 0.07 & 50.29 & 49.64 & PSU \\
\hline U1324B-68X-4, 60-62 & 555.80 & 0.62 & 61.91 & 37.47 & PSU \\
\hline U1324B-69X-2, 60-62 & 562.50 & 1.50 & 48.49 & 50.01 & MIT \\
\hline U1324B-70X-1, 59-61 & 570.59 & 0.12 & 37.48 & 62.40 & PSU \\
\hline U1324B-70X-3, 62-64 & 573.62 & 0.17 & 44.63 & 55.20 & PSU \\
\hline U1324B-70X-6-1 & 578.13 & 0.03 & 38.17 & 61.80 & PSU \\
\hline U1324B-71X-1, 62-64 & 580.22 & 0.11 & 50.66 & 49.23 & PSU \\
\hline U1324B-71X-3, 59-62 & 583.19 & 10.90 & 76.14 & 12.96 & PSU \\
\hline U1324B-73X-1, 60-62 & 593.80 & 4.41 & 51.78 & 43.81 & PSU \\
\hline U1324B-74X-5, 64-66 & 605.24 & 5.68 & 71.10 & 23.22 & PSU \\
\hline U1324B-74X-6, 59-61 & 606.19 & 0.16 & 50.68 & 49.16 & PSU \\
\hline
\end{tabular}

Note: PSU = the Pennsylvania State University, MIT = Massachusetts Institute of Technology. 
Table T3. Nomenclature.

\begin{tabular}{lll}
\hline Name & \multicolumn{1}{c}{ Definition } & Dimensions \\
\hline$\eta$ & Viscosity of water & $\mathrm{MT} / \mathrm{L}^{2}$ \\
$D$ & Diameter of particle & $\mathrm{L}$ \\
$G_{\mathrm{s}}$ & Specific gravity of sediment & Dimensionless \\
$L$ & Effective depth & $\mathrm{L}$ \\
$t$ & Elapsed time & $\mathrm{T}$ \\
$M$ & Dry sediment mass & $\mathrm{M}$ \\
$R_{\mathrm{h}}$ & Corrected hydrometer reading on sample tube & $\mathrm{M} / \mathrm{L}^{3}$ \\
$B$ & Corrected hydrometer reading on reference tube & $\mathrm{M} / \mathrm{L}^{3}$ \\
\hline
\end{tabular}

Table T4. Specific gravity measurements of 19 samples. (See table note.)

\begin{tabular}{lrccc}
\hline $\begin{array}{c}\text { Hole, core, } \\
\text { section }\end{array}$ & $\begin{array}{c}\text { Depth } \\
\text { (mbsf) }\end{array}$ & $\begin{array}{c}\text { Test } \\
\text { number }\end{array}$ & Description & $\begin{array}{c}\text { Specific } \\
\text { gravity }\end{array}$ \\
\hline 308- & & & & \\
U1324C-1H-1 & 0.50 & SG002 & CRS799 & 2.744 \\
U1324B-4H-7 & 31.78 & SG001 & CRS800 & 2.735 \\
U1324B-4H-7 & 32.70 & SG016 & CRS013 & 2.686 \\
U1324C-1H-1 & 51.00 & SG017 & CRS799 & 2.649 \\
U1324B-7H-7 & 59.30 & SG005 & Natural & 2.733 \\
U1324B-7H-7 & 59.30 & SG006 & Oven dried & 2.736 \\
U1324B-7H-7 & 59.30 & SG009 & CRS802 & 2.680 \\
U1324B-10H-7 & 88.80 & SG011 & CRS813 & 2.674 \\
U1324C-2H-4 & 104.50 & SG019 & CRS807 & 2.665 \\
U1324B-15H-5 & 135.00 & SG003 & CRS803 & 2.766 \\
U1324B-16H-5 & 141.50 & SG007 & Natural & 2.742 \\
U1324B-16H-5 & 141.50 & SG008 & Oven dried & 2.735 \\
U1324B-16H-5 & 141.50 & SG013 & CRS801 & 2.716 \\
U1324B-23H-5 & 199.80 & SG018 & CRS812 & 2.671 \\
U1322D-2H-2 & 5.80 & SG004 & CRS796 & 2.746 \\
U1322B-4H-3 & 27.17 & SG015 & CRS815 & 2.668 \\
U1322D-2H-2 & 72.00 & SG020 & CRS798 & 2.680 \\
U1322B-15H-1 & 125.80 & SG010 & CRS808 & 2.694 \\
U1322B-18H-6 & 157.30 & SG012 & CRS810 & 2.689 \\
\hline & & & & \\
\hline
\end{tabular}

Note: CRS = constant-rate-of-strain consolidation test . 